OPEN ACCESS

Edited by:

Eliane Hajnsdorf,

UMR 8261 Expression Génétique

Microbienne, France

Reviewed by:

Benjamin Ezraty,

Centre National de la Recherche

Scientifique (CNRS), France

Jay Mellies,

Reed College, United States

*Correspondence:

Ulrike Kappler

u.kappler@uq.edu.au

tThese authors have contributed equally to this work

Specialty section:

This article was submitted to Microbial Physiology and Metabolism,

a section of the journal

Frontiers in Microbiology

Received: 03 December 2020

Accepted: 07 January 2021

Published: 12 February 2021

Citation:

Nasreen M, Fletcher A, Hosmer J,

Zhong Q, Essilfie A-T, McEwan AG and Kappler U (2021) The Alternative

Sigma Factor RpoE2 Is Involved in the Stress Response to Hypochlorite and in vivo Survival of Haemophilus influenzae.

Front. Microbiol. 12:637213. doi: 10.3389/fmicb.2021.637213

\section{The Alternative Sigma Factor RpoE2 Is Involved in the Stress Response to Hypochlorite and in vivo Survival of Haemophilus influenzae}

\author{
Marufa Nasreen ${ }^{1 \dagger}$, Aidan Fletcher ${ }^{1+}$, Jennifer Hosmer ${ }^{1}$, Qifeng Zhong', \\ Ama-Tawiah Essilfie ${ }^{2}$, Alastair G. McEwan ${ }^{1}$ and Ulrike Kappler ${ }^{1 *}$ \\ ${ }^{1}$ Australian Infectious Diseases Research Centre, School of Chemistry and Molecular Biosciences, The University \\ of Queensland, St. Lucia, QLD, Australia, ${ }^{2}$ QIMR Berghofer Medical Research Institute, Herston, QLD, Australia
}

Extracytoplasmic function (ECF) sigma factors underpin the ability of bacteria to adapt to changing environmental conditions, a process that is particularly relevant in human pathogens that inhabit niches where human immune cells contribute to high levels of extracellular stress. Here, we have characterized the previously unstudied RpoE2 ECF sigma factor from the human respiratory pathogen $H$. influenzae $(\mathrm{Hi})$ and its role in hypochlorite-induced stress. Exposure of $\mathrm{H}$. influenzae to oxidative stress $(\mathrm{HOCl}$, $\mathrm{H}_{2} \mathrm{O}_{2}$ ) increased rpoE2 gene expression, and the activity of RpoE2 was controlled by a cytoplasmic 67-aa anti-sigma factor, HrsE. RpoE2 regulated the expression of the periplasmic MsrAB peptide methionine sulfoxide reductase that, in $\mathrm{H}$. influenzae, is required for $\mathrm{HOCl}$ resistance, thus linking RpoE2 to $\mathrm{HOCl}$ stress. Interestingly, a Hi $\triangle r p o E 2$ strain had wild-type levels of resistance to oxidative stress in vitro, but HisrpoE2 survival was reduced 26-fold in a mouse model of lung infection, demonstrating the relevance of this sigma factor for $\mathrm{H}$. influenzae pathogenesis. The HiRpoE2 system has some similarity to the ECF sigma factors described in Streptomyces and Neisseria sp. that also control the expression of msr genes. However, HiRpoE2 regulation extended to genes encoding other periplasmic damage repair proteins, an operon containing a DoxX-like protein, and also included selected OxyRcontrolled genes. Based on our results, we propose that the highly conserved HiRpoE2 sigma factor is a key regulator of $H$. influenzae responses to oxidative damage in the cell envelope region that controls a variety of target genes required for survival in the host.

Keywords: extracytoplasmic function sigma factor, $H$. influenzae, hypochlorite, gene regulation, stress response

\section{INTRODUCTION}

Extracytoplasmic function (ECF) sigma factors are one of the major signal transduction systems in bacteria and enable responses to a variety of environmental stimuli (Helmann, 2002; Staroń et al., 2009). Genes encoding ECF sigma factors are found in the majority of bacterial genomes, and at least 94 phylogenetically distinct groups of ECF sigma factors are known at present 
(Staroń et al., 2009; Pinto and Mascher, 2016). A distinguishing trait of ECF sigma factors is that their activity is inhibited by a socalled anti-sigma factor (ASF), which sequesters the ECF sigma factor until activation occurs through a variety of mechanisms (Mascher, 2013).

While ECF sigma factors are often highly abundant in versatile bacteria that can inhabit a wide range of environments, hostadapted bacteria tend to contain fewer of these alternative sigma factors. This is the case in the human respiratory pathobiont $H$. influenzae where only two ECF sigma factor-encoding genes are present. $H$. influenzae is a typical commensal bacterium of the nasopharyngeal microbiome, but it is also a major causative agent of acute respiratory tract infections such as otitis media, sinusitis, and pneumonia (Pettigrew et al., 2012; Slack, 2015). Additionally, $H$. influenzae is an early airway colonizer in cystic fibrosis and exacerbates several chronic respiratory tract diseases such as chronic obstructive pulmonary disease, bronchiectasis, and asthma (Essilfie et al., 2012; King, 2012; Finney et al., 2014; Van Eldere et al., 2014; King and Sharma, 2015). Current clinical isolates of $H$. influenzae are predominantly unencapsulated, non-typeable strains (NTHi), for which an increase in disease severity has been reported (Soeters et al., 2018). These traits, in combination with the increasing antibiotic resistance of isolate strains, have led to $H$. influenzae being classified as a WHO priority pathogen (Tristram et al., 2007; Macneil et al., 2011; King, 2012; Van Eldere et al., 2014; Wan Sai Cheong et al., 2015; World Health Organization., 2017; Soeters et al., 2018).

Clinical specimens of tissues affected by NTHi are characterized by high levels of host-induced oxidative stress and often show signs of hyperinflammation and tissue damage caused by the release of reactive chlorine or oxygen species (RCS and ROS, respectively), such as hypochlorite, superoxide, and hydrogen peroxide (Harrison et al., 2012, 2015; King, 2012). Oxidative stress can cause significant damage to the bacterial cell envelope, lipids, proteins, and DNA, where specific repair mechanisms are required that, in many bacterial species, have been shown to be controlled by ECF sigma factors (Gangaiah et al., 2014; Park et al., 2019). However, the function of ECF sigma factors in $H$. influenzae has only received limited attention so far. It was shown that $H$. influenzae genomes encode an ECF sigma factor that is closely related to the well-studied, envelope stress-induced RpoE sigma factor from Escherichia coli, and this ECF sigma factor was required for $H$. influenzae survival during infection of a macrophage cell line (Craig et al., 2002).

In this study, we describe for the first time the function of a second $H$. influenzae ECF sigma factor, RpoE2, that is located in a gene region that also encodes a periplasmic peptide methionine sulfoxide reductase, MsrAB, which is required for resistance of $H$. influenzae to oxidative damage caused by hypochlorous acid $(\mathrm{HOCl})$ both in vitro and during infection (Nasreen et al., 2020). We have characterized the HiRpoE2/ASF system, its role in oxidative stress resistance, and its contribution to the survival of $H$. influenzae in a mouse model of infection. We also compare HiRpoE2 to related systems from Neisseria gonorrhoeae, Neisseria meningitidis, and Streptomyces coelicolor that control the expression of $m s r$ genes (Paget et al., 1998; Gunesekere et al., 2006; Hopman et al., 2010).

\section{MATERIAL AND METHODS}

\section{Bacterial Strains, Media, and Growth Conditions}

The bacterial strains and plasmids used in this study are listed in Supplementary Tables 1, 2. E. coli strains were cultured at $37^{\circ} \mathrm{C}$ using Luria-Bertani (LB) broth (Ausubel, 2002) with shaking at $200 \mathrm{rpm}$ or statically on LB agar $(1.5 \%, w / v)$ plates. Where necessary, LB was supplemented with $100 \mu \mathrm{g} / \mathrm{ml}$ ampicillin, $50 \mu \mathrm{g} / \mathrm{ml}$ spectinomycin, $20 \mu \mathrm{g} / \mathrm{ml}$ kanamycin, and/or $30 \mu \mathrm{g} / \mathrm{ml}$ trimethoprim.

$H$. influenzae strains were cultured either in $\mathrm{BBL}^{\mathrm{TM}}$ Brain Heart Infusion (BHI) broth (Becton Dickinson) supplemented with $10 \mu \mathrm{g} / \mathrm{ml}$ hemin and $10 \mu \mathrm{g} / \mathrm{ml} \beta$-nicotinamide adenine dinucleotide (NAD) (Johnston, 2010) or in chemically defined media (CDM) (RPMI 1640) (Sigma-Aldrich, R6504-1L): 24 mM sodium bicarbonate, $786 \mu \mathrm{M}$ uracil, $25 \mathrm{mM}$ HEPES ( $\mathrm{pH} 7.5$ ), $10 \mathrm{mM}$ glucose, $7.5 \mathrm{mM}$ inosine, $1 \mathrm{mM}$ sodium pyruvate, $10 \mu \mathrm{g} / \mathrm{ml} \mathrm{NAD}$, and $10 \mu \mathrm{g} / \mathrm{ml}$ hemin) under microaerobic (5\% $\mathrm{CO}_{2}$ and $\left.3.7 \% \mathrm{O}_{2}\right)$, aerobic $\left(5 \% \mathrm{CO}_{2}\right)$, or anaerobic $\left(5 \% \mathrm{CO}_{2}\right.$, no oxygen) conditions at $37^{\circ} \mathrm{C}$, with shaking at $200 \mathrm{rpm}$ for aerobic and microaerobic conditions (Coleman et al., 2003). Difco $^{\text {TM }}$ BHI (Becton Dickinson) and CDM $(1.5 \%, w / v)$ agar plates were incubated at $37^{\circ} \mathrm{C}$ with $5 \% \mathrm{CO}_{2}$. Where appropriate, $\mathrm{BHI}$ and $\mathrm{CDM}$ were supplemented with $20 \mu \mathrm{g} / \mathrm{ml}$ kanamycin and/or $50 \mu \mathrm{g} / \mathrm{ml}$ spectinomycin.

\section{Growth of $\boldsymbol{H}$. influenzae in the Presence of $\mathrm{HOCl}$}

Hi2019 ${ }^{\mathrm{WT}}$ and Hi2019 ${ }^{\Delta \text { rpoE2 }}$ cell material freshly grown on CDM agar plates was used to inoculate the CDM broth to $\mathrm{OD}_{600}=0.05$. HOCl (10-15\% sodium hypochlorite; Sigma Aldrich) was added to cultures in increasing concentrations $(0-1,000 \mu \mathrm{M})$, and $200 \mu \mathrm{l}$ of each culture were immediately added to a roundbottom 96-well microtiter plate (Greiner Bio-One) in replicate $(n=3)$. The plates were incubated under microaerobic conditions $\left(2.8 \% \mathrm{O}_{2}\right.$ and $\left.5 \% \mathrm{CO}_{2}\right)$ at $37^{\circ} \mathrm{C}, 200 \mathrm{rpm}$ in a Clariostar multimode plate reader (BMG Labtech). $\mathrm{OD}_{600}$ measurements were recorded every $15 \mathrm{~min}$ for $24 \mathrm{~h}$.

\section{Bactericidal Assays}

$H$. influenzae cell material freshly grown on supplemented brain heart infusion (sBHI) plates was resuspended to an $\mathrm{OD}_{600 \mu l}$ of 1.0 in $1 \mathrm{x}$ sterile phosphate-buffered saline (PBS). Of the bacterial culture, $900 \mu \mathrm{l}$ were then combined with $100 \mu \mathrm{l}$ of a freshly prepared 10x stock of the test compound, incubated at room temperature with gentle orbital shaking for $1 \mathrm{~h}$ followed by immediate serial dilution (up to $10^{-7}$ ) in $\mathrm{BHI}$, and plating on sBHI plates. Assays used 25-250 $\mu \mathrm{M} \mathrm{HOCl,} \mathrm{100-750} \mathrm{mM}$ $\mathrm{H}_{2} \mathrm{O}_{2}, 1-5 \mathrm{mM}$ paraquat, or 1-7 $\mu \mathrm{g} / \mathrm{ml}$ polymyxin. Serummediated killing assays were performed as previously published (Lichtenegger et al., 2017). Hi2019 was grown to mid-log phase 
$\left(\mathrm{OD}_{600 \mathrm{~nm}}\right.$ of $\left.0.5-0.6\right)$ and then harvested $\left(800 \times g, 10 \mathrm{~min}, 20^{\circ} \mathrm{C}\right)$ and resuspended in $1 \mathrm{x}$ PBS supplemented with $0.5 \%$ bovine serum albumin (BSA), $5 \mathrm{mM} \mathrm{MgCl}_{2}$, and $1 \mathrm{mM} \mathrm{CaCl}_{2} .2 \times 10^{7}$ bacteria/ml were incubated with $0-10 \%$ serum for $45 \mathrm{~min}$ at $37^{\circ} \mathrm{C}$, followed by serial dilution.

\section{Biofilm Formation}

Biofilm formation and bacterial survival in biofilms were tested as in Dhouib et al. (2016). Hi2019 cell material from a freshly grown CDM plate was used to inoculate $20 \mathrm{ml} \mathrm{CDM}$ to $\mathrm{OD}_{600}=0.05$, followed by incubation at $37^{\circ} \mathrm{C}, 200 \mathrm{rpm}$, until $\mathrm{OD}_{600}=0.2-$ 0.3 was reached. For anaerobic conditions, bacteria were grown in CDM in completely filled 10 - or $50-\mathrm{ml}$ tubes and incubated at $37^{\circ} \mathrm{C}$, without shaking in a $\mathrm{CO}_{2}$ incubator. For the assay, all cultures were diluted to an $\mathrm{OD}_{600}$ of 0.05 and $100 \mu \mathrm{l} /$ well were added to U-bottom 96-well microtiter plates (TechnoPlas). Plates were incubated statically at $37^{\circ} \mathrm{C}, 5 \% \mathrm{CO}_{2}$, for $16 \mathrm{~h}$. For anaerobic conditions, plates were incubated in an anaerobic jar using Anaerocult catalysts (Merck) to remove oxygen. Detection of biofilm formation used crystal violet staining, as in Schembri and Klemm (2001). Viable cells present in the biofilm were determined by incubating each well with $200 \mu \mathrm{l}$ of $0.1 \mathrm{mg} / \mathrm{ml}$ proteinase $\mathrm{K}$ for $10 \mathrm{~min}$ to dissolve the biofilm, followed by serial dilution (up $10^{-7}$ in $\mathrm{BHI}$ ) and plating on sBHI plates for CFU/well determination.

\section{Tissue Cell Infection Assays}

16HBE14 human bronchial epithelial cells were used for adherence and invasion assays, essentially as described in Dhouib et al. (2016). In brief, 16HBE14 cells were infected with Hi2019 (MOI $=100: 1$, bacteria:tissue cells) for 4 or $24 \mathrm{~h}$. To determine titers of total adherent bacteria (i.e., all bacteria associated extraor intracellularly with $16 \mathrm{HBE} 14$ cells), infected tissue cell layers were washed several times with fresh medium to remove nonadherent bacteria, lysed using $1 \%$ saponin, and serial dilutions of the lysate were plated on sBHI agar plates. To determine titers of internalized bacteria, infected tissue cells were treated with gentamycin $(50 \mu \mathrm{g} / \mathrm{ml})$ in MEM for $1 \mathrm{~h}$ prior to the wash steps and lysis.

\section{Mouse Model of Lung Infection}

Experimental animal procedures were carried out in strict accordance with the recommendations in the Qld Animal Care and Protection ACT (2001) and the Australian Code of Practice for the Care and Use of Animals for Scientific Purposes, eighth edition. The protocols were approved by the Animal Care and Ethics Committees of QIMR Berghofer and the University of Queensland (QIMR/050/19). BALB/c female mice (6-7 weeks old) were inoculated intranasally with $30 \mu \mathrm{l}$ of a bacterial suspension containing $10^{7}$ CFUs, as described in Dhouib et al. (2016). Groups of five mice were euthanized and necropsied at $0,6,24,48$, and $72 \mathrm{~h}$. To quantify bacterial recovery, lungs were aseptically removed, homogenized in $1 \mathrm{ml} 1 \times$ sterile PBS, and serially diluted in the same buffer, followed by plating of the dilutions on sBHI plates. Bronchoalveolar lavage fluid (BALF) was also collected and CFU/ml determined. CFUs per lung were calculated as in Essilfie et al. (2011, 2012), and Essilfie et al. (2015).
BALF was also cytocentrifuged and stained with May-GrunwaldGiemsa reagent (Merck) as per the manufacturer's protocol and total immune cell numbers enumerated.

\section{Molecular Biology Methods}

Standard methods were used throughout (Ausubel, 2002). PCR purification and plasmid isolation used the Wizard SV Gel and PCR Clean-Up System (Promega) and either the Genejet (Thermo Fisher Scientific) or Purelink Quick (Invitrogen) Plasmid Miniprep Kit, respectively. Genomic DNA was isolated using the Genomic DNA mini kit (Life Technologies). All kits were used according to the manufacturers' instructions. Restriction enzymes were from Invitrogen or NEB. ANZAT4 ligase Mastermix (Invitrogen) or T4 ligase (NEB) were used for cloning. Standard PCR reactions used Gotaq Green Mastermix (Promega), high-fidelity PCR amplifications used Phusion Flash Mastermix (Thermo). Genomic DNA (gDNA) and PCR products were visualized using agarose gels $(1-2 \%, w / v)$ in $1 \mathrm{x}$ TAE buffer, 1x SYBR ${ }^{\circledR}$ safe DNA gel stain (Invitrogen), and a $1-\mathrm{kb}$ plus DNA ladder (Thermo). DNA quantification used a Nanodrop spectrophotometer (Thermo Fisher Scientific). Transformation of $E$. coli used the calcium chloride method (Hanahan et al., 1991).

\section{Construction of Protein Expression Plasmids}

Plasmids for the expression of RpoE2 or RpoE2 and the HrsE ASF with an N-terminal hexa-histidine Tag on RpoE2 were constructed using pProex-HTb (Invitrogen). Genes encoding the protein(s) of interest were amplified by PCR (Supplementary Tables 1, 2) and inserted into the plasmid following digestion with the appropriate restriction enzymes. Positive clones were confirmed via PCR using a combination of gene- and plasmid-specific primers (Supplementary Table 2). Expression of the target proteins was verified using LB cultures grown at $37^{\circ} \mathrm{C}$ and $200 \mathrm{rpm}$ to an $\mathrm{OD}_{600 \mathrm{~nm}}$ of $0.6-0.8$ before the addition of $0.1 \mathrm{mM}$ IPTG and further incubation at $37^{\circ} \mathrm{C}$ and $200 \mathrm{rpm}$ overnight. Protein expression was verified using SDS-PAGE, protein purification used a HisGraviTrap column ( $1 \mathrm{ml}$, Cytiva) according to the manufacturer's instructions, and 50-500 $\mathrm{mM}$ imidazole was used to elute the overexpressed proteins.

\section{Construction of pMU2385 Reporter Gene Plasmids}

Fusions of Hi2019 gene promoter regions to a promoterless lacZ gene used the pMU2385 plasmid (Praszkier et al., 1992). Regions (245-865 bp) directly upstream of the coding regions of the Hi2019 genes rpoE2 (gene: C645_RS08430, 284 and $865 \mathrm{bp}$ ), $m s r A B$ (252 bp), and dmt (gene: C645_RS08420, $245 \mathrm{bp}$ ) were amplified and cloned into the EcoRI and BamHI restriction sites of pMU2385. Insertion was confirmed by PCR and DNA sequencing. 


\section{Construction of a Hi2019 ${ }^{\triangle r p o E 2}$ Strain}

To create a BamHI restriction site in the rpoE2 coding sequence, a 1,571-bp and a 1,201-bp DNA fragment containing the HirpoE2 gene and flanking up- and downstream DNA regions were amplified from Hi2019 gDNA (Supplementary Tables 1, 2), digested with $\mathrm{SacI} /$ BamHI and EcoRI/BamHI, respectively, and cloned into the SacI and EcoRI sites of pBluescriptII SK(+) (Stratagene) creating pBlue_HirpoE2. The kanamycin cassette from pUC4K (Vieira and Messing, 1982) was amplified using primers pUC4K_PCR_F and R, digested with BamHI, and inserted into pBlue_HirpoE2, leading to the formation of pBlue_HirpoE2_IS_kan. pBlue_HirpoE2_IS_kan was linearized with ScaI and transformed into Hi2019 ${ }^{\mathrm{WT}}$ using the protocol of Poje and Redfield (2003), M-IV solution and H. influenzae grown on $\mathrm{BHI}$ to an $\mathrm{OD}_{600}$ of $0.2-0.4$. Cultures were pelleted and washed in $20 \mathrm{ml}$ pre-warmed M-IV solution [described in Poje and Redfield (2003)]. Cell pellets were resuspended in $5 \mathrm{ml}$ pre-warmed M-IV solution and incubated at $37^{\circ} \mathrm{C}$ for $100 \mathrm{~min}$ with $90 \mathrm{rpm}$ shaking to develop competence. $1 \mu \mathrm{g}$ of linearized plasmid was added to $500 \mu \mathrm{l}$ of competent cells and incubated at $37^{\circ} \mathrm{C}, 5 \% \mathrm{CO}_{2}$, for $30 \mathrm{~min}$. Two milliliters of $\mathrm{BHI}$ broth was added to each transformation reaction, followed by another hour of incubation at $37^{\circ} \mathrm{C}, 5 \% \mathrm{CO}_{2}$. The cells were washed once in $\mathrm{BHI}$, resuspended in $1 \mathrm{ml} \mathrm{BHI}$, plated on selective media, and incubated in a $\mathrm{CO}_{2}$ incubator at $37^{\circ} \mathrm{C}$ for $16-24 \mathrm{~h}$. Colonies were screened by PCR to identify strains carrying the gene knockout mutation.

\section{RNA Isolation and cDNA Synthesis}

$H$. influenzae strains were grown under aerobic, microaerobic, and anaerobic conditions in $\mathrm{CDM}$ glucose to $\mathrm{OD}_{600} \sim 0.6$ (aerobic and microaerobic) or to $\mathrm{OD}_{600} \sim 0.4$ for the anaerobic conditions. Two milliliters of the culture was added to $2 \mathrm{ml}$ of RNA Protect Bacteria reagent (Qiagen), mixed by inversion, and incubated at room temperature for $5 \mathrm{~min}$. Preserved bacterial cells were pelleted at $22,369 \times g$ for $5 \mathrm{~min}$ and stored at $-80^{\circ} \mathrm{C}$ for up to a week. Collection of RNA samples after exposure to oxidative stress reagents $(200 \mu \mathrm{M} \mathrm{HOCl}, 5 \mathrm{mM}$ paraquat, and $\left.150 \mu \mathrm{M} \mathrm{H}_{2} \mathrm{O}_{2}\right)$ used microaerobic cultures $(200 \mathrm{ml}$ medium $/ 250 \mathrm{ml}$ flask, $200 \mathrm{rpm}$ ) where the untreated sample $(t=0)$ was collected immediately before the addition of treatment and the additional samples after 30,60, and $120 \mathrm{~min}$ of further incubation.

RNA was isolated using the Illustra RNAspin Mini kit (Cytiva), followed by gDNA removal (Turbo DNA Free Kit; Life Technologies) and cleanup of the reactions using the RNAspin Mini kit. RNA was quantified using a Qubit fluorimeter (Life Technologies). gDNA removal was assessed using PCR. cDNA was synthesized from $500 \mathrm{ng}$ gDNA-free RNA using Superscript IV reverse transcriptase (Life Technologies).

\section{Quantitative RT-PCR}

Quantitative reverse transcription PCR (qRT-PCR) was performed in 384-well plates as described in Othman et al. (2014) and Dhouib et al. (2016). Each reaction $(10 \mu \mathrm{l})$ contained $2 \mu \mathrm{l}$ of diluted cDNA (typically 1:100), $5 \mu \mathrm{l}$ Quantinova SYBR green qPCR Mastermix (Qiagen), and primers at optimized concentrations between 0.5 and $2 \mu \mathrm{M}$ (Supplementary Table 2). The cycle threshold (CT) values for all samples were determined using QuantstudioTM software version 1.3 (Thermo Fisher Scientific). PCR efficiencies were determined using LinReg Software version 2016.0 (Ruijter et al., 2009). The gyrA gene was used as the reference gene for relative quantification.

\section{Biochemical Methods}

Standard methods were used throughout (Coligan, 2003; Ausubel et al., 2005). Protein concentrations were determined using the BCA-1 kit (Sigma-Aldrich). SDS-PAGE was performed as in Laemmli (1970) using a Low Molecular Weight Calibration Kit for SDS electrophoresis (Cytiva).

\section{Beta-Galactosidase Assay}

Reporter gene assays were performed as described in Miller (1972). In brief, $5 \mathrm{ml}$ LB supplemented with ampicillin $(100 \mu \mathrm{g} / \mathrm{ml})$ and trimethoprim $(30 \mu \mathrm{g} / \mathrm{ml})$ were inoculated to $\mathrm{OD}_{600}$ of 0.05 from overnight cultures of $E$. coli JM109 $\lambda$ pir carrying combinations of pMU2385/pProex Htb plasmids (Supplementary Table 3). Cultures were incubated at $37^{\circ} \mathrm{C}$, $200 \mathrm{rpm}$, to an $\mathrm{OD}_{600}$ of $0.4-0.8$, harvested $\left(2,370 \times \mathrm{rcf}, 4^{\circ} \mathrm{C}\right.$, $10 \mathrm{~min}$ ), and resuspended in an equal volume of $1 \mathrm{x}$ PBS. $150 \mu \mathrm{l}$ of resuspended bacteria was added to an equal volume of Z-buffer (0.06 $\mathrm{M} \mathrm{Na}_{2} \mathrm{HPO}_{4}, 0.06 \mathrm{M} \mathrm{NaH}_{2} \mathrm{PO}_{4}, 0.01 \mathrm{M} \mathrm{KCl}, 0.001 \mathrm{M}$ $\mathrm{MgSO}_{4} \times 7 \mathrm{H}_{2} \mathrm{O}$, and $2.7 \mathrm{ml} / \mathrm{l} \beta$-mercaptoethanol, $\left.\mathrm{pH} 7.0\right)$ and solubilized using $10 \mu \mathrm{l} \%(w / v)$ SDS and $10 \mu \mathrm{l}$ chloroform. The cultures were vortexed for $10 \mathrm{~s}$ and the reaction started by addition of $50 \mu \mathrm{l}$ of $o$-nitrophenyl- $\beta$-D-galactoside $(4 \mathrm{mg} / \mathrm{ml}$ in $0.1 \mathrm{M}$ potassium phosphate buffer, $\mathrm{pH}$ 7.0) and incubation in a $30^{\circ} \mathrm{C}$ water bath. Reactions were stopped on appearance of a yellow color by the addition of $125 \mu \mathrm{l} 1 \mathrm{M} \mathrm{Na}_{2} \mathrm{CO}_{3}$, cell debris removed by centrifugation, and $\mathrm{OD}_{420}$ measured using microtiter plates. Miller units were calculated as in Miller (1972).

\section{Bioinformatic and Phylogenetic Analyses}

RpoE2 and HrsE sequences from different $H$. influenzae strains were accessed $v i a$ the NCBI website [35 sequence (RpoE2) and 27 sequence (HrsE/ASF) variants/alleles found in $713 \mathrm{H}$. influenzae genomes]. The sequences were imported into the MEGA phylogenetic analysis software in Fasta format and aligned using Clustal Omega (Sievers et al., 2011) as incorporated into the MEGA7 software package (Kumar et al., 2016). Phylogenetic tress were created in MEGA7 based on this alignment using the Neighbor-Joining method and bootstrapping (500 cycles) for robustness testing.

In silico promoter analyses were carried out for the Hi2019 $m s r A B, r p o E 2$, and the Dmt transporter protein encoding genes using the Prodoric Virtual Footprint website ${ }^{1}$ (Münch et al., 2005). Promoter and transcription factor binding site predictions used a 250 -nt gene region from -200 to +50 of the selected genes and were obtained from the Hi2019 genome (acc. no. NZ_CP008740.1). Binding motifs found in the Virtual Footprint database (Münch et al., 2005) were used to test for

\footnotetext{
${ }^{1}$ http://www.prodoric.de/vfp/, accessed 28/12/2020
} 
the presence of sigma factor and transcription factor binding consensus sequences.

\section{Statistical Analyses}

All data were analyzed using Microsoft Excel (2016; Microsoft, WA) and GraphPad Prism (8.2.1; GraphPad Software Inc., CA, United States). Two-tailed $t$ tests were used to compare the mean CFU in the lung and in BALF at each time point. All other analyses used two-way ANOVA wherever possible. Šidák's multiple comparisons test was used where applicable. A $p$ equal to or $<0.05$ was considered statistically significant.

\section{RESULTS}

\section{The $\boldsymbol{H}$. influenzae ECF Sigma Factor RpoE2 Controls Expression of Genes Encoding Proteins Essential for Oxidative Stress-Dependent Protein Repair}

In the $H$. influenzae strain 2019 (Campagnari et al., 1987), the rpoE2 gene encoding the second $H$. influenzae ECF sigma factor is located in the same gene region as the $m s r A B$ operon that encodes the $\mathrm{HOCl}$-inducible $\mathrm{MsrAB}$ peptide methionine sulfoxide reductase (Nasreen et al., 2020; Figure 1A). A gene encoding a putative DMT family (drug/metabolite) transporter (“dmt," C645_RS08420, COG0697) separates the msrAB operon from rpoE2 and a gene encoding a small (67-amino acids, aa) putative cytoplasmic protein (Figure 1A). To test whether HiRpoE2 controls expression of $m s r A B$ and other genes present in this gene region, we fused the promoter regions (245-865 bp) for $m s r A B, \operatorname{rpoE2}$, and the $d m t$ gene to the promoterless lacZ gene in pMU2385 (Praszkier et al., 1992) and tested the ability of HiRpoE2 to induce beta-galactosidase activity using E. coli JM109 as a host. The controls used pMU2385 and pProex-Htb plasmids without inserts (Figure 1 and Supplementary Figure 1).

The Hims $A B$ promoter was strongly activated in the presence of RpoE2 (3,640 \pm 302 Miller units, MU), but showed low residual activity (95 $\pm 11 \mathrm{MU})$ already in the absence of HiRpoE2 (Figure 1B). The $d m t$ promoter also showed high activity in the presence of RpoE2 (4,264 $\pm 11 \mathrm{MU})$, but combined with a strong, RpoE2-independent activity $(863 \pm 70 \mathrm{MU})$ that was 9-fold higher than for the $m s r A B$ promoter (Figure 1C). The RpoE2-independent induction of the $m s r A B$ and $d m t$ promoters indicates the presence of a second promoter in the upstream region of both genes.

To test the ability of HiRpoE2 to control the promoter of the rpoE2 gene, we used both a 284-bp and an extended 865bp region upstream of $r p o E 2$ that covers the large intergenic region upstream of $r p o E 2$ (Figures $\mathbf{1 A}, \mathbf{D}$ ). Only baseline activity was observed for the 284-bp rpoE2 promoter $(7.7 \pm 0.1 \mathrm{MU})$, but a slight RpoE2-dependent activation was observed for the 865-bp promoter region (control $=11.4 \pm 3.5 \mathrm{MU}$, RpoE2 $=95 \pm 13 \mathrm{MU}$ ), indicating a very limited ability of RpoE2 to control the expression of the gene that encodes it (Figure 1D).
We also demonstrated that the small gene that encodes a 67aa protein is co-transcribed with HirpoE2, indicating a possible functional link (Figure 1E).

Together, these data clearly demonstrate that HiRpoE2 controls the expression of $\mathrm{Hims} A B$, and since we have previously shown that $m s r A B$ is involved in the resistance of $H$. influenzae to $\mathrm{HOCl}$, it suggested that RpoE2 mediates a response to oxidative stress or $\mathrm{HOCl}$ in $\mathrm{H}$. influenzae.

\section{The msrAB-rpoE2 Gene Region Is Highly Conserved in $\boldsymbol{H}$. influenzae Genomes}

Analysis of 713 publicly available $H$. influenzae genomes revealed that both the rpoE2 gene and the gene encoding a small putative ASF protein are completely conserved in all strains. Further analyses identified $33 \mathrm{HiRpoE} 2$ protein sequence variants with an average of $93 \%$ sequence identity. Thirty of these sequence variants ( $97 \%$ average sequence identity) formed two closely related clades, with three sequences being more divergent [ $85 \%(n=1)$ and $75 \%(n=2)$ sequence identity] (Figure 2A). The presence of small cytoplasmic ASFs is a typical feature of group 13 ECF sigma factors, to which HiRpoE2 belongs, and our analyses revealed the existence of 27 HiRpoE2 ASF sequence variants that also formed two closely related groups with three additional divergent sequence types (Supplementary Figure 2). The three more divergent sequence variants identified for RpoE2 and the putative ASF belong to a group of $H$. influenzae strains identified in the same study (Roach et al., 2015) and that show only 67 and $39.7 \%$ symmetrical identity to the most closely related $H$. influenzae genomes, explaining the relatively larger divergence of their RpoE2 and ASF sequences. In fact, the most divergent sequences (RpoE2: WP_049364416.1, ASF: WP_049364417.1) also occur in two strains of Haemophilus parainfluenzae.

The high conservation extended to the rpoE2 gene region, which in the majority of strains was identical to the one found in Hi2019 (Figure 1A). However, variations occurred in a minority of $H$. influenzae strains (representatives of RpoE2 sequence types WP_005693910.1, WP_005662386.1, WP_044334451.1, and WP_048949909.1), where three genes, excluding a $d m t$ transporter-encoding gene, separated the $m s r A B$ and $r p o E 2$ operons. In two additional groups of strains (WP_049367789.1 and WP_049364416.1, both of them representing the divergent RpoE2 sequence types), the $m s r A B$ operon was located at a distant chromosomal location.

Overall, the high sequence identity of HiRpoE2 and ASF proteins and their presence in the $H$. influenzae core genome indicate strong functional conservation.

\section{The HiRpoE2 ASF Is Related to ASFs From Neisseria and Streptomyces sp. and Controls the Activity of HiRpoE2}

To determine whether the putative $H$. influenzae ASF can control RpoE2 activity, we then carried out a functional evaluation of the ASF protein using a protein expression plasmid, pProexHiRpoE2-ASF, designed to express an N-terminally His-tagged 
A

\section{ASF hrsE}

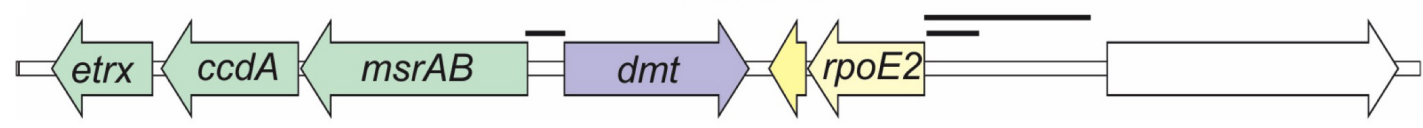

B msrAB promoter
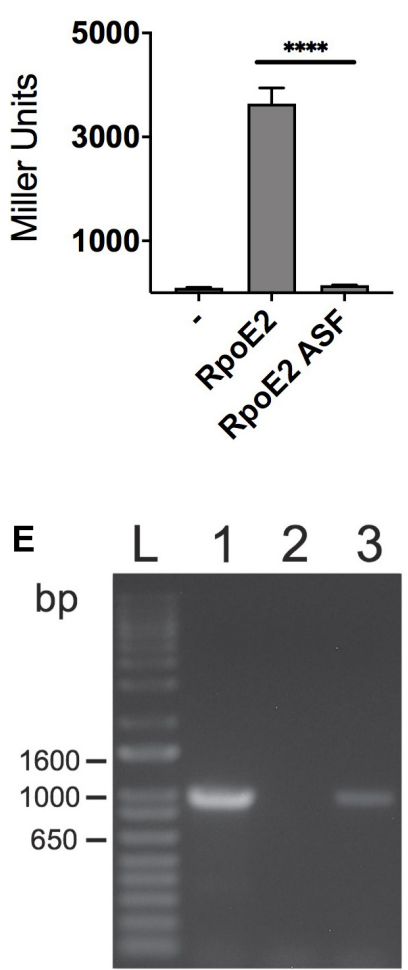

C dmt promoter

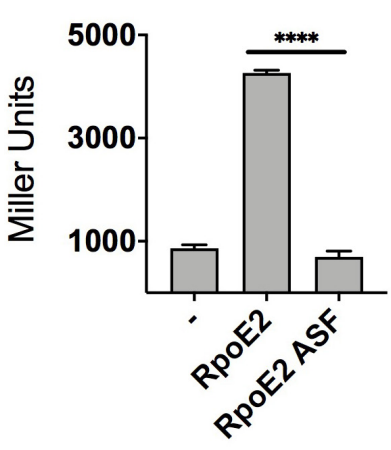

D $\quad$ rpoE2 promoter regions

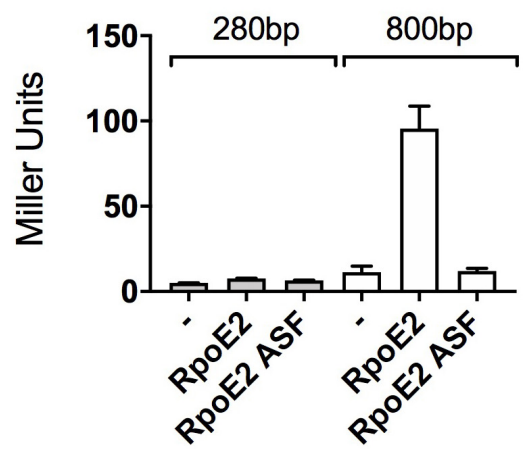

$\mathbf{F}$

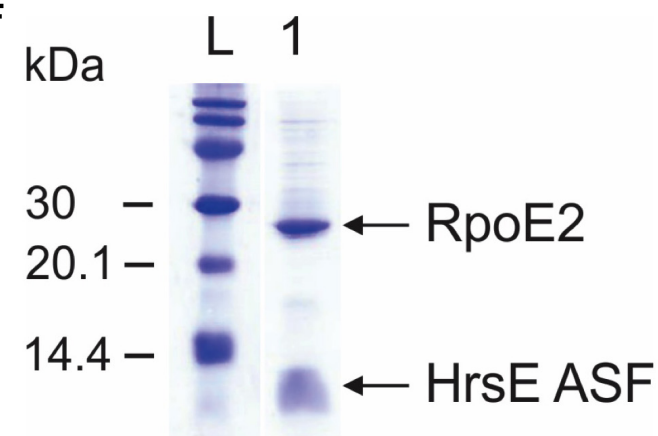

FIGURE 1 | RpoE2 and its cognate anti-sigma factor (ASF), HseR, control the expression of neighboring genes encoding a peptide methionine sulfoxide reductase ( $m s r A B$ ) and a dmt-type transporter (dmt). (A) Schematic overview of the Hi2019 rpoE2-encoding gene region. Black bars indicate the promoter regions used in the reporter gene assays shown in other panels. (B-D) Activities of $H$. influenzae msrAB (B), $d m t$ (C), and rpoE2 (D) promoter regions in the lac $Z$ reporter gene assays in Escherichia coli Jm109. Activity was tested in the presence of RpoE2 (label: RpoE2) and RpoE2 co-expressed with the HrsE ASF (label: RpoE2-ASF) and in the absence of specific inducer proteins (label: -). (E) Co-transcription analysis showing that, in H. influenzae, the genes encoding rpoE2 and hrsE are co-transcribed. Lane 1, positive control, gDNA; lane 2, negative control, no template; lane 3, Hi2019 cDNA. (F) Co-purification of recombinant 6xHis-HiRpoE2 and the HrsE ASF after heterologous expression in E. coli. ${ }^{\star \star \star *} p<0.0001$.

RpoE2 protein and an untagged ASF protein. Following protein expression using this plasmid, the two proteins co-purified (Figure 1F), and the identity of the co-purifying small protein was confirmed by protein sequencing (Supplementary Table 4). Reporter gene assays then showed that the presence of the putative ASF abolished the activation of the $m s r A B$ promoter by RpoE2, confirming that this 67 -aa protein is indeed an effective RpoE2-ASF, and we have therefore named it HrsE (Haemophilus Regulator of Sigma E) (Figure 1B). Reporter gene assays also showed that the observed activation of both the $d m t$ and rpoE2 promoters was reversible in the presence of HiHrsE (Figures 1C,D).

The HiHrsE ASF shares similarity with two characterized peptide ASFs from N. meningitidis and S. coelicolor that are also associated with ECF group 13 sigma factors (Kang et al., 1999;
Hopman et al., 2010; Kallifidas et al., 2010). The two characterized sequences contain a so-called ZAS motif $\left(\mathrm{C} / \mathrm{H}-\mathrm{X}_{23}-26-\mathrm{H}-\mathrm{X}_{3}-\right.$ $\mathrm{C}-\mathrm{X}_{2}-\mathrm{C}$ ) that mediates the binding of a functionally relevant zinc ion (Newman et al., 2001; Paget et al., 2001; Ilbert et al., 2006; Hopman et al., 2010), and these residues are conserved in HiHrsE (Supplementary Figure 3).

\section{Oxidative Stress Increases Expression of HirpoE2}

Given its potential role in regulating the response to oxidative stress, we then tested the expression of HirpoE2 in the presence and absence of $\mathrm{H}_{2} \mathrm{O}_{2}, \mathrm{HOCl}$, and paraquat using qRT-PCR. We also investigated the expression of HirpoE2 in response to 
A

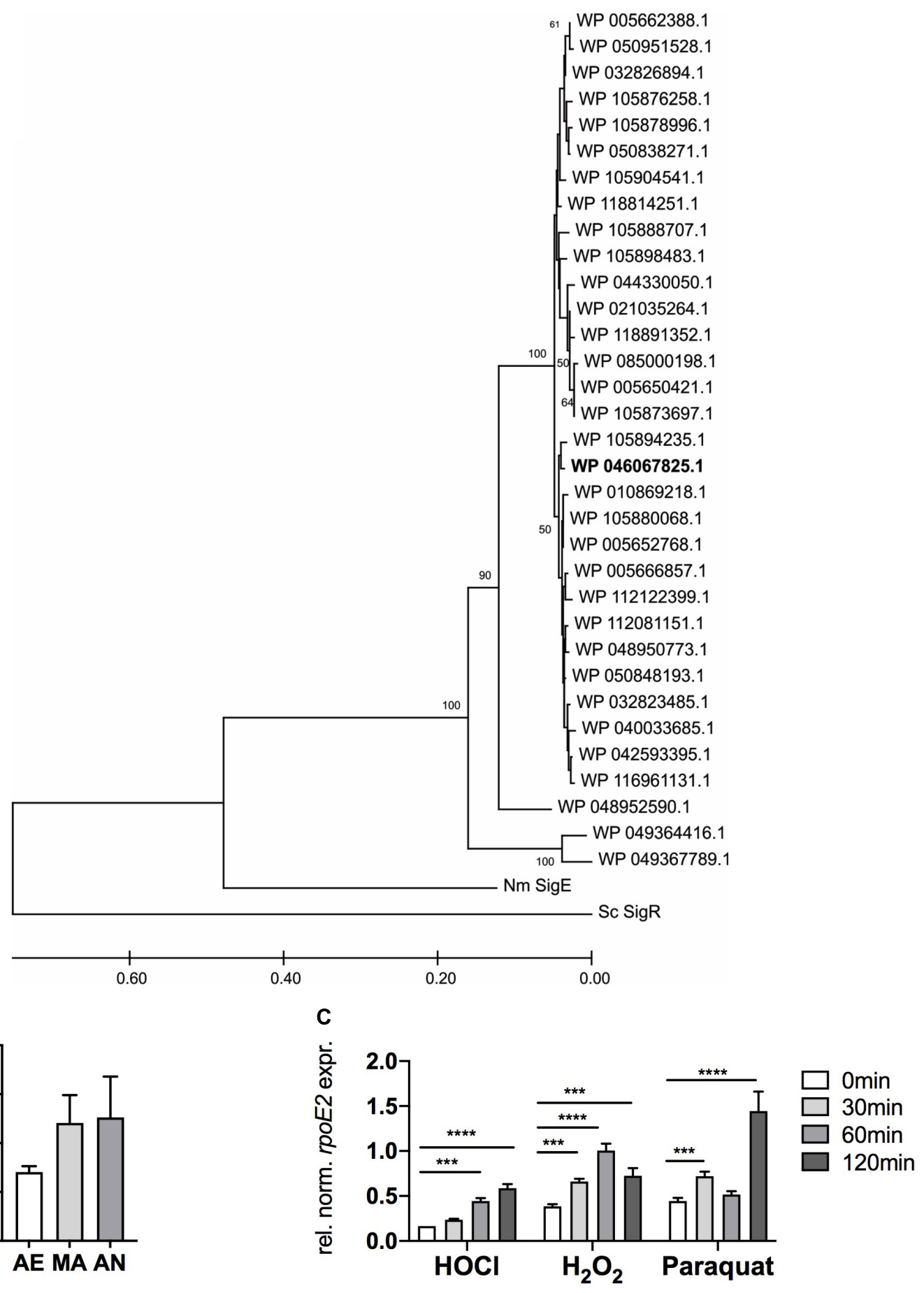

FIGURE 2 | RpoE2 is highly conserved in H. influenzae strains and rpoE2 gene expression increases following exposure to oxidative stress. (A) Phylogenetic relationships between the RpoE2 sequence variants found in $\mathrm{H}$. influenzae strains. The phylogenetic tree was created using the neighbor-joining method with robustness testing using 500 bootstrap cycles. The majority of the HiRpoE2 protein sequences formed two related clades, while the remaining $10 \%$ formed a small cluster of slightly more divergent sequences (96\% sequence identity to the main cluster). Three sequence types (WP_005650421.1, $n=153$; WP_005666857.1, $n=75$; and WP_005662388.1, $n=175$ ) accounted for 403 or 56.5\% of the sequences analyzed. The Hi2019 RpoE2 belongs to the WP_046067825.1 sequence type (in bold). HiRpoE2-related sequences from Neisseria meningitidis Nm3682 ("Nm SigE", AlZ23068.1) and Streptomyces coelicolor A3(2) SigR ("Sc SigR", CAB94601.1) were used as outgroups. (B) Expression of HirpoE2 under aerobic (AE), microaerobic (MA), and anaerobic (AN) conditions. (C) Effects of hypochlorous acid $(\mathrm{HOCl}, 200 \mu \mathrm{M}), \mathrm{H}_{2} \mathrm{O}_{2}(150 \mu \mathrm{M})$, and paraquat $(5 \mathrm{mM})$ on expression of HirpoE2 over time. Gene expression data from qRT-PCR (B,C) are reported as relative expressions after normalization to the expression of the $H$. influenzae gyrA gene. Statistical testing used two-way ANOVA. ${ }^{* \star *} p<0.0001$, ${ }^{* \star *} p<0.001$. 
different oxygen tensions that the bacteria may encounter during infection and host colonization.

In the absence of oxidative stress treatments, rpoE2 expression increased moderately when the oxygen concentrations decreased (Figure 2B). Low oxygen tensions are typical at sites of infection and in biofilms.

Following treatment with $200 \mu \mathrm{M} \mathrm{HOCl}, r p o E 2$ expression increased steadily over the $120 \mathrm{~min}$ of experimental time (3.6-fold maximum induction) (Figure 2C), while after $\mathrm{H}_{2} \mathrm{O}_{2}$ treatment $(150 \mu \mathrm{M})$, rpoE2 expression peaked at $60 \mathrm{~min}$ postexposure (2.6-fold induction) and then started to decrease. In contrast, paraquat exposure $(5 \mathrm{mM})$ resulted in a bimodal expression pattern with a small increase of expression after $30 \mathrm{~min}$ (1.6-fold) and a large increase after $120 \mathrm{~min}$ (3.1fold). This second expression peak may not be associated with the ROS generated by the initial paraquat exposure, but may reflect a secondary response to derivative oxidizing compounds. While $\mathrm{HOCl}$ and $\mathrm{H}_{2} \mathrm{O}_{2}$ both triggered increases in rpoE2 expression, the responses were relatively slow, taking at least $60 \mathrm{~min}$ to reach peak expression (Figure 2C). This is not consistent with the strong 2.5-fold increase in $m s r A B$ gene expression observed within $30 \mathrm{~min}$ of treatment with HOCl (Nasreen et al., 2020), which indicates that de novo RpoE2 synthesis is likely a secondary response to ROS or RCS exposure and that RpoE2 molecules already present in $H$. influenzae mediate the initial fast response to $\mathrm{HOCl}$ and, possibly, $\mathrm{H}_{2} \mathrm{O}_{2}$ treatment. The different expression patterns of $m s r A B$ and $r p o E 2$ also suggest that there may be differences in the types of oxidizing agents that inactivate the HiHrsE ASF compared to those that trigger rpoE2 gene expression.

\section{Loss of RpoE2 Does Not Significantly Increase the Sensitivity of $\boldsymbol{H}$. influenzae to Oxidative Stress}

To elucidate the role of RpoE2 in $H$. influenzae physiology, we constructed a $\mathrm{Hi2019^{ \triangle }}{ }^{\triangle p o E 2}$ mutant strain and verified it using PCR. As a Hi2019 ${ }^{\triangle m s r A B}$ strain was sensitive to $\mathrm{HOCl}$ mediated killing and RpoE2 controls the expression of $m s r A B$, we expected to see a similar phenotype for the Hi2019 ${ }^{\Delta r p o E 2}$ strain. However, contrary to expectations, killing assays with $\mathrm{HOCl}, \mathrm{H}_{2} \mathrm{O}_{2}$, or paraquat showed that $\mathrm{Hi2019}{ }^{\Delta r p o E 2}$ was not more susceptible to killing by either of these substances than Hi2019 ${ }^{\mathrm{WT}}$ (Figures 3A,B and Supplementary Figure 4).

In the absence of oxidative stress, biofilm formation and survival in the biofilm, physiological traits essential for H. influenzae virulence, were also unaffected by the rpoE2 mutation (Figures 3C,D). However, in the presence of increasing amounts of $\mathrm{HOCl}$ (up to $1 \mathrm{mM}$ ), biofilm formation for Hi2019WT increased slightly up to $0.7 \mathrm{mM} \mathrm{HOCl} \mathrm{(a} \mathrm{1.3-}$ fold increase), while for Hi2019 ${ }^{\triangle r p o E 2}$ biofilm formation did not change throughout (Figure 3E). For microaerobic growth in the presence of $\mathrm{HOCl}$, the growth rates for Hi2019 ${ }^{\Delta r p o E 2}$ consistently declined starting from $150 \mu \mathrm{M} \mathrm{HOCl}$, while for the wild type (WT) no change in the growth rate was observed at concentrations up to $450 \mu \mathrm{M}$ (Figure 3F). In summary, while the loss of RpoE2 did not lead to a change in susceptibility to ROS or RCS killing, there were subtle changes in the growth rates and biofilm formation that may have some relevance in vivo.

\section{Hi2019 ${ }^{\Delta r p o E 2}$ Showed Wild-Type Infection Levels of Cultured Tissue Cells, but Was Attenuated in a Mouse Model of Lung Infection}

ROS and RCS such as $\mathrm{HOCl}$ are usually encountered during contact with host cells, so we tested the survival of the Hi2019 ${ }^{\triangle r p o E 2}$ strain in two different models of infection. During infection of $16 \mathrm{HBE} 14$ human bronchial epithelial cells, the Hi2019 ${ }^{\triangle r p o E 2}$ strain showed no difference in planktonic survival, adherence to, or invasion of the tissue cells compared to the wild type ( $n=3$ independent experiments) (Figures 4A-C). This was

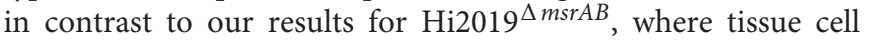
invasion was impaired (Nasreen et al., 2020).

However, in a mouse model of lung infection, the survival of Hi2019 ${ }^{\Delta \text { rpoE2 }}$ was clearly attenuated compared to the Hi2019WT strain. Bacterial loads in BALF steadily decreased compared to $\mathrm{Hi} 2019^{\mathrm{WT}}$, from a 1.3 -fold reduction after $6 \mathrm{~h}$ to a 6.7 fold reduction after $72 \mathrm{~h}$ (all $p<0.0001,2$-way ANOVA) (Figures 4D,E). In contrast, the survival of the mutant strain in lung tissue was not affected during the first $24 \mathrm{~h}$ of the experiment, but a significant reduction in bacterial loads (26and 4-fold, $p<0.0001,2$-way ANOVA) was observed after 48 and $72 \mathrm{~h}$ of infection (Figures 4D,E). During the experiment, the numbers of neutrophils and macrophages present in the lung tissue increased to similar levels for both $H$. influenzae strains, however, for Hi2019 ${ }^{\triangle r p o E 2}$, the increase was somewhat delayed. While after $6 \mathrm{~h}$ of infection, the neutrophil and macrophage numbers in BALF had increased 21-fold for Hi2019 ${ }^{\mathrm{WT}}$ compared to the uninfected control; for Hi2019 ${ }^{\Delta r p o E 2}$ only a 4-fold increase $(p<0.0001,2$-way ANOVA) was seen (Figure 4F). This documents a role for RpoE2 in supporting $H$. influenzae virulence in a whole animal model of infection, despite the absence of a strong oxidative stress-related phenotype during the in vitro characterization of the mutant strain.

\section{HiRpoE2 Controls the Expression of Genes Involved in Methionine Sulfoxide Repair and Also Affects Expression of Oxidative Stress Defense Genes Controlled by OxyR}

Despite the fact that RpoE2 is required for expression of MsrAB, which mediates $H$. influenzae resistance to $\mathrm{HOCl}$ stress (Nasreen et al., 2020), the Hi2019 ${ }^{\Delta \text { rpoE2 }}$ strain lacked a strong oxidative stress-related phenotype, and this prompted us to assess expression of genes involved in oxidative stress defense in $\mathrm{Hi} 2019^{\Delta \text { rpoE2 }}$.

We included the RpoE2-regulated $m s r A B$ and $d m t$ genes and a gene encoding another periplasmic methionine sulfoxide reductase, $m t s Z$, that we characterized earlier (Dhouib et al., 2016). Additionally, the sodA gene encoding superoxide 

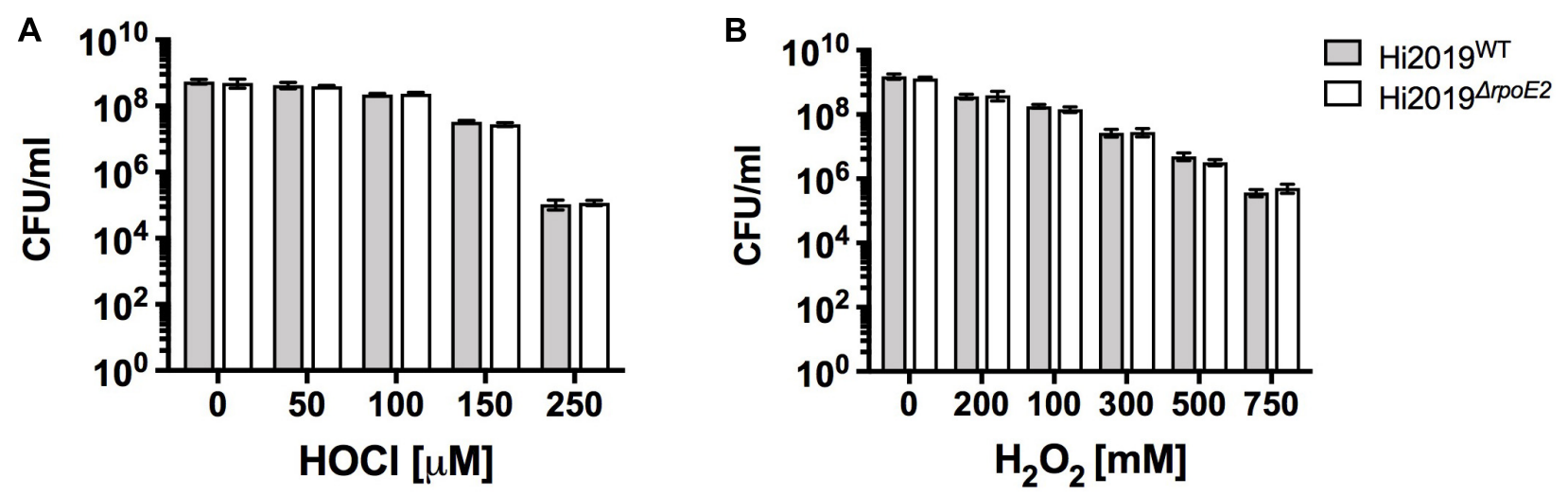

C

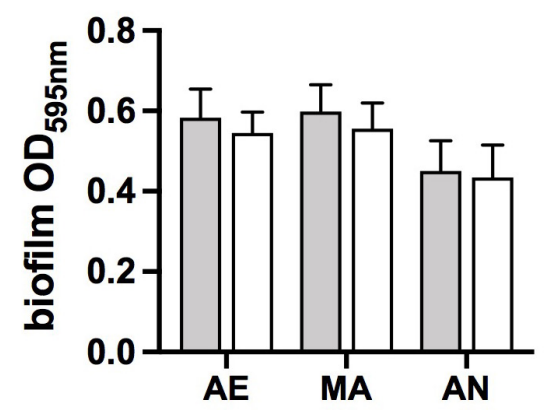

E

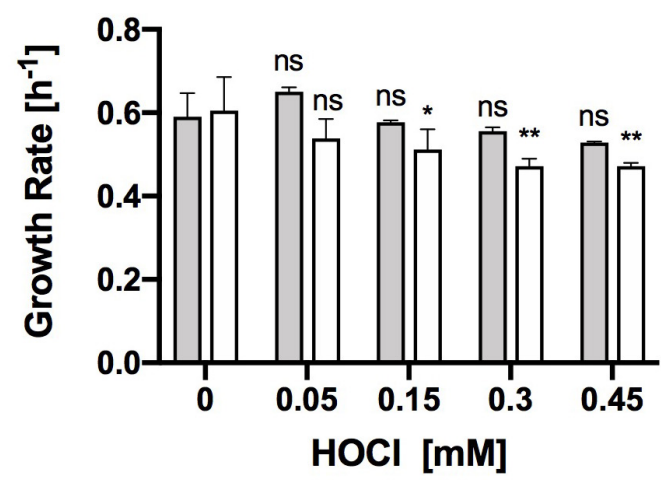

D

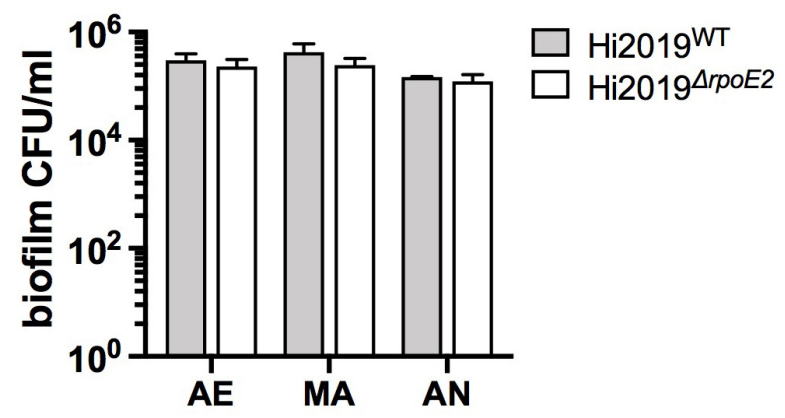

F

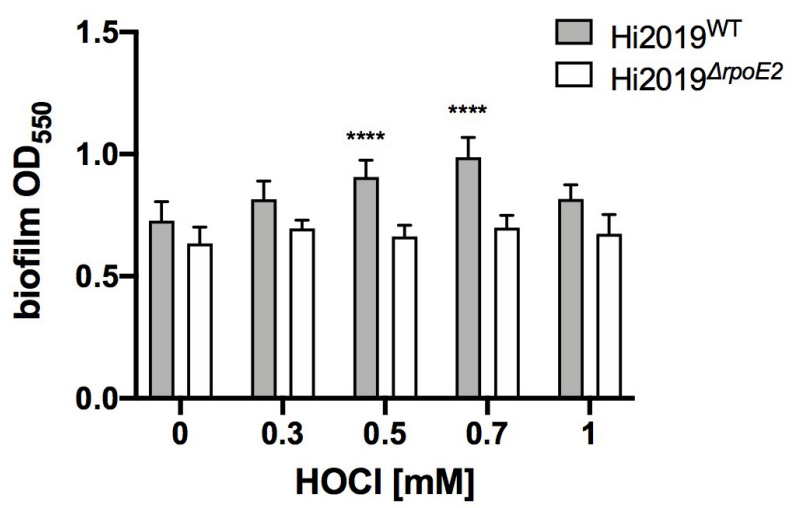

FIGURE 3 | A Hi2019 ${ }^{\Delta r p o E 2}$ strain showed no increase in oxidative stress sensitivity and only slight changes in growth and biofilm formation in the presence of $\mathrm{HOCl}$. (A,B) Killing of Hi2019WT and Hi2019 ${ }^{\Delta r p o E 2}$ by exposure to increasing concentrations of $\mathrm{HOCl}$ (A) and $\mathrm{H}_{2} \mathrm{O}_{2}$ (B). (C,D) Biofilm formation (C) and biofilm survival (D) of Hi2019WT and Hi2019 ${ }^{\Delta r p o E 2}$ under microaerobic and anaerobic conditions in the absence of oxidative stress. (E) Growth rates of Hi2019WT and Hi2019 ${ }^{\Delta r p o E 2}$ in the presence of increasing amounts of hypochlorous acid (HOCl). (F) Biofilm formation under microaerobic conditions of Hi2019WT and Hi2019 ${ }^{\Delta r p o E 2}$ in the presence of increasing amounts of HOCl. Gray bars, Hi2019WT; white bars, Hi2019 ${ }^{\Delta r p o E 2}$. Statistical analyses (two-way ANOVA, strain-time or strain-conc.) returned non-significant changes for the comparisons between Hi2019WT and Hi2019 ${ }^{\Delta r p o E 2}$ at the same time point or concentration for panels (A-D). For panels (E,F) all Hi2019WT or Hi2019 ${ }^{\Delta r p o E 2}$ values were compared to the control (no HOCl) sample for the same strain; values are shown directly above each bar. ${ }^{*} p<0.05,{ }^{* *} p<0.01,{ }^{* * * *} p<0.0001$.

dismutase (Kroll et al., 1993) and the OxyR-regulated genes encoding catalase $(h k t E)$, peroxiredoxin $(p g d X)$, and the ferritinlike DPS protein $(d p s)$, all of which are induced by exposure of $\mathrm{H}$. influenzae to $\mathrm{H}_{2} \mathrm{O}_{2}$ (Harrison et al., 2007; Whitby et al., 2012), were included.

As shown previously (Nasreen et al., 2020), expression of $m s r A B$ was strongly induced within $30 \mathrm{~min}$ of $\mathrm{HOCl}$ exposure in $\mathrm{Hi} 2019^{\mathrm{WT}}$, while in $\mathrm{Hi} 2019^{\Delta r p o E 2}$ after $30 \mathrm{~min}$ of $\mathrm{HOCl}$ treatment, $m s r A B$ expression was actually reduced 2 -fold, while expression at 60 and $120 \mathrm{~min}$ slightly increased compared to $t=0 \mathrm{~min}$ (Figure 5A ). We propose that this residual expression of the $m s r A B$ gene might explain the lack of a $\mathrm{HOCl}$-sensitivity phenotype in $\mathrm{Hi} 2019^{\Delta r p o E 2}$, as it would allow for the production of a basal level of MsrAB protein. Expression of the $d m t$ gene 

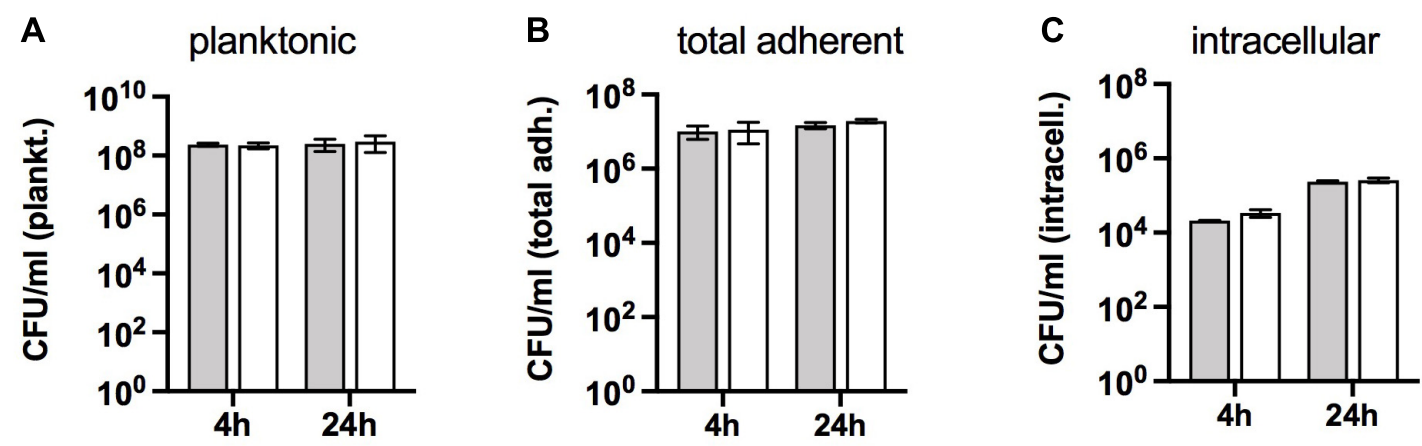

D

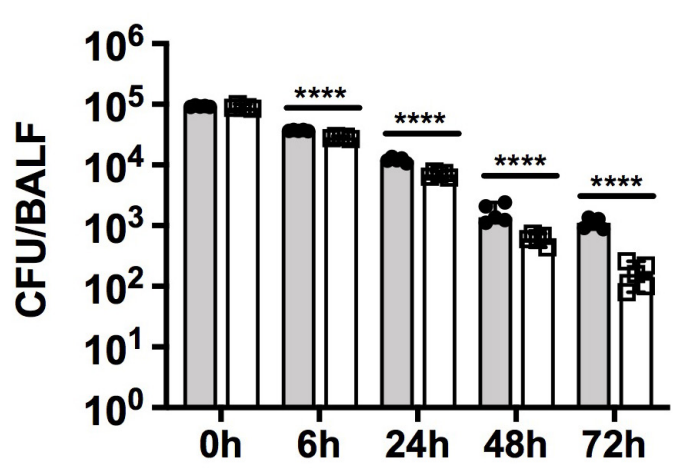

$\mathbf{F}$

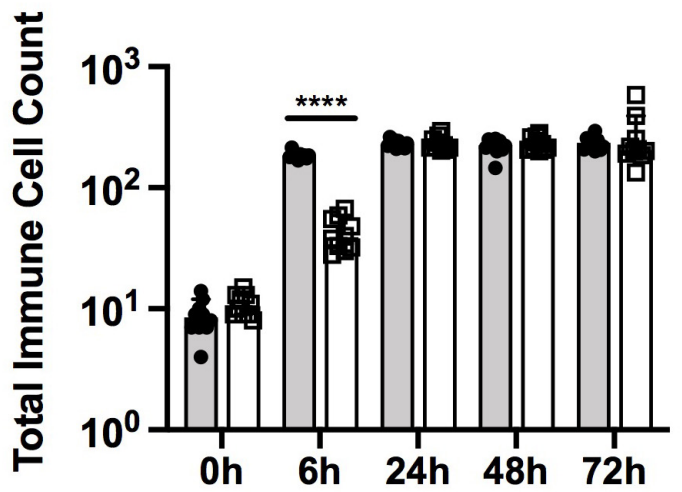

E

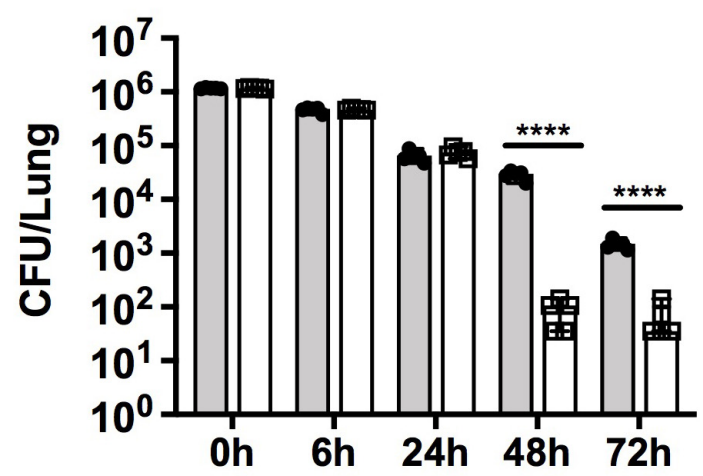

FIGURE 4 | Survival of Hi2019WT and Hi2019 ${ }^{\Delta r p o E 2}$ in different models of H. influenzae infection. (A-C) Infection of $16 H B E 14$ tissue cells. Planktonic (A), total adherent (B), and intracellular (C) bacteria preferred notation - CFU/ml are shown after 4 and 24 h of infection. (D-F) Survival of Hi2019WT and Hi2019 ${ }^{\Delta r p o E 2}$ in a mouse model of lung infection. Bacterial cell numbers (in CFU) are shown per bronchoalveolar lavage fluid (BALF) (D) and lung tissue (E). Giemsa staining was used to determine immune cell (neutrophil and macrophage) count changes over time in BALF (F). Gray bars, Hi2019WT; white bars, Hi2019 ${ }^{\Delta r p o E 2}$. Statistical analyses used Student's $t$ tests, comparing CFU for Hi2019WT and Hi2019 ${ }^{\Delta r p o E 2}$ at each time point. ${ }^{* \star * *} p<0.0001$.

that is located between the $m s r A B$ and $r p o E 2$ operons was significantly lower in $\mathrm{Hi} 2019^{\Delta r p o E 2}$ compared to Hi2019 ${ }^{\mathrm{WT}}$ prior to HOCl treatment (1.6-fold reduction, $p=0.03$, 2-way ANOVA), but showed $\mathrm{HOCl}$-dependent induction with peak expression reached after $60 \mathrm{~min}$ in both strains (Figure 5A). We attribute this expression pattern to the second, RpoE2-independent promoter identified as part of the reporter gene assays.

Interestingly, expression of the $m t s Z$ gene that encodes an enzyme that reduces free MetSO to Met (Dhouib et al., 2016) showed a similar pattern to $m s r A B$, with strong induction within $30 \mathrm{~min}$ in $\mathrm{Hi2019}{ }^{\mathrm{WT}}$ and only residual expression in the $\mathrm{Hi2} 2019^{\Delta \text { rpoE2 }}$ strain, suggesting that the expression of $m t s Z$ is also controlled by RpoE2 (Figure 5B).

In contrast, expression of the four genes known to be part of the general oxidative stress defense in $H$. influenzae was much less affected by the loss of RpoE2 (Figure 5C). While a decrease in the basal gene expression levels prior to $\mathrm{HOCl}$ treatment was observed for $p g d X$, sodA, and $d p s$ (Figure 5C), expression levels 

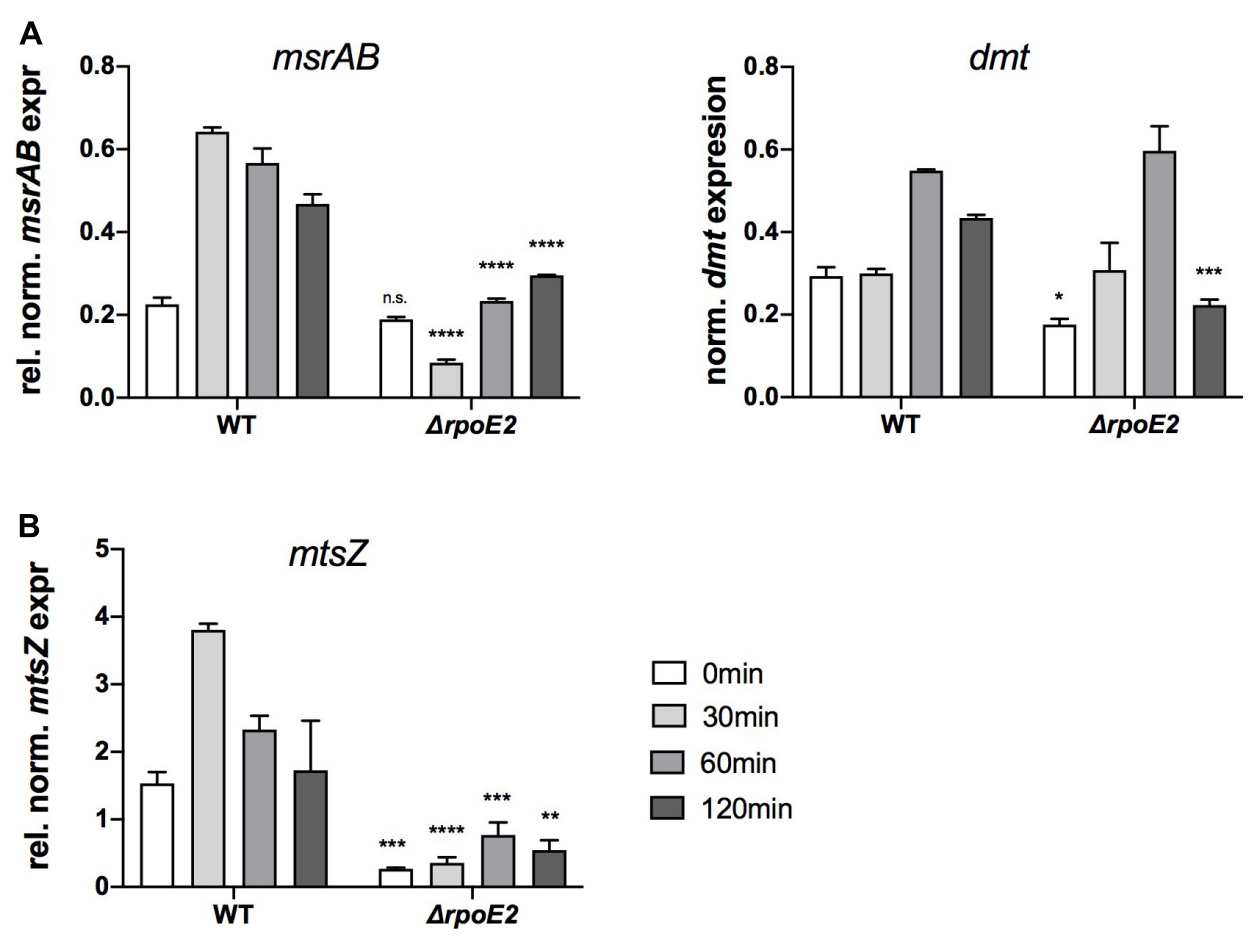

C
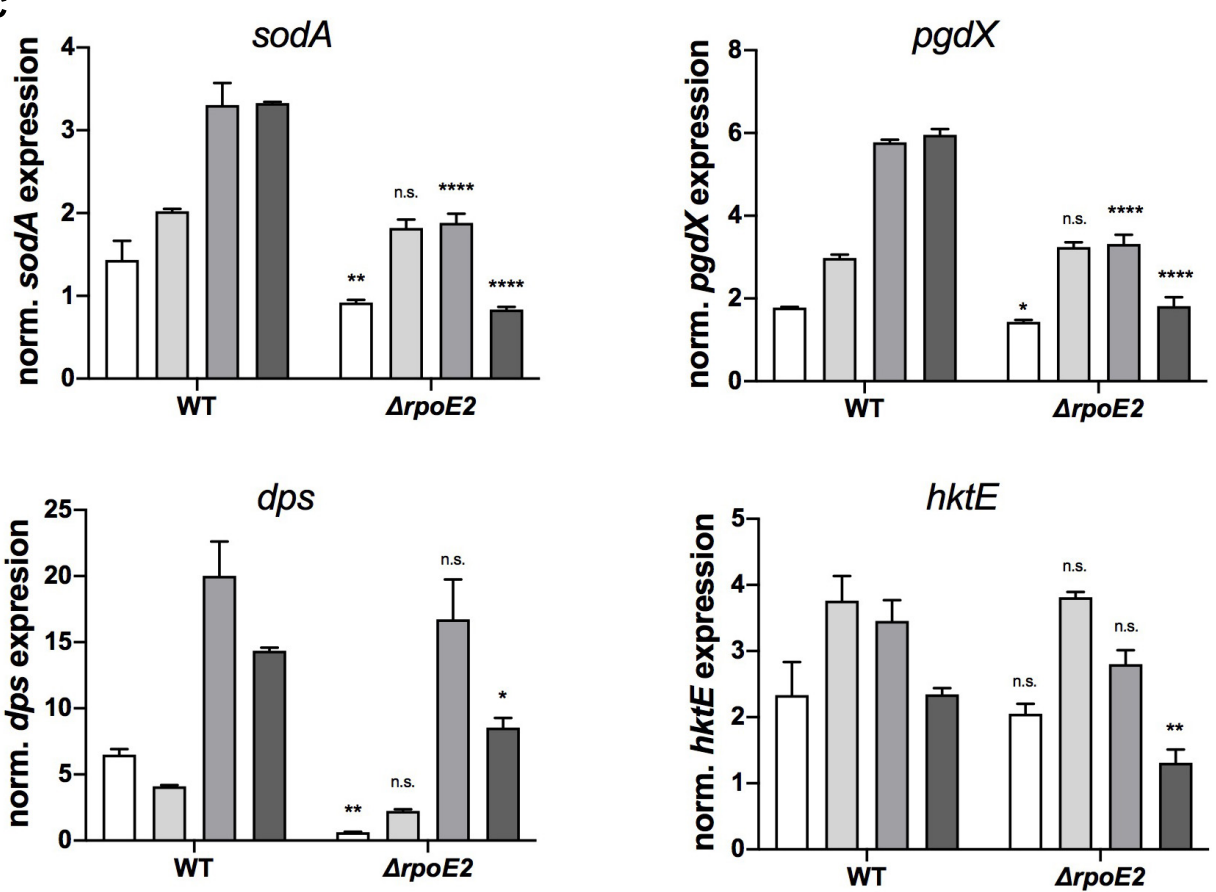

FIGURE $\mathbf{5}$ | Expressions of putative RpoE2-regulated genes (A,B) and genes encoding proteins known to be involved in $H$. influenzae oxidative stress response (C) in Hi2019 ${ }^{W T}$ and Hi2019 ${ }^{\Delta r p o E 2}$ following exposure to $200 \mu \mathrm{M} \mathrm{HOCl}$. (A) Expressions of the RpoE2-regulated $m s r A B$ and dmt genes. (B) Expression of a gene ( $m t s Z$ ) encoding MtsZ, a periplasmic Mo-containing methionine sulfoxide reductase. (C) Expressions of genes encoding superoxide dismutase (sodA), peroxiredoxin $(\mathrm{pgd} X)$, catalase $(h k t E)$, and the ferritin-like protein Dps (dps). $h k t E, d p s$, and $p g d X$ are part of the $H$. influenzae OxyR regulon. Gene expression data generated by qRT-PCR are reported as relative expressions after normalization to the expression of the gyrA gene. Statistical testing of expression changes relative to Hi2019 WT used two-way ANOVA. Statistically significant changes are indicated above the bars representing the gene expression of $\mathrm{Hi}_{201} 019^{\Delta r p o E 2} .{ }^{\star} p<0.05,{ }^{* \star} p<0.01$, ${ }^{\star \star \star} p<0.001,{ }^{\star \star \star \star *} p<0.0001 ;$ n.s., not significant. 
of catalase $(h k t E)$ and $d p s$ were essentially unaltered in Hi2019 ${ }^{\mathrm{WT}}$ and $\mathrm{Hi} 2019^{\triangle \mathrm{rpoE} 2}$ up to $60 \mathrm{~min}$ post-HOCl exposure, but showed a reduction at $120 \mathrm{~min}$. The $\operatorname{sodA}$ and $p g d X$ genes showed a statistically significant reduction in peak expression, which in these genes occurred after 60 and $120 \mathrm{~min}$, respectively.

\section{HiRpoE2 Controls Expression of Genes Homologous to Members of the N. meningitidis SigE Regulon}

Our analyses so far indicate that the HiRpoE2 regulatory system resembles the SigE regulon from $N$. meningitidis, where the ECF sigma factor SigE controls expression of the Nmtrx-msrAB gene, a sigE small RNA (sRNA) and 10 additional genes encoding outer membrane proteins, a NirK-like protein, the SigE and ASF proteins, and a cluster of three hypothetical proteins and a DoxX family protein (Gunesekere et al., 2006; Hopman et al., 2010). Analyses of the Hi2019 genome identified a gene cluster encoding proteins identical to the DoxX gene cluster from Neisseria (Hi2019 genes C645_RS07455-C645_Rs07470) (Figures 6A-D). These proteins showed significant homology to their Neisseria counterparts, while with the exception Hims $A B$ and a gene encoding an opacity-associated outer membrane protein (Hi2019 gene C645_RS07000), no homologs of any of the other NmSigE target genes or the Neisseria sigE sRNA were identified in Hi2019.

Following exposure to $\mathrm{HOCl}$, expression levels of the DoxX cluster genes in Hi2019 ${ }^{\mathrm{WT}}$ and Hi2019 ${ }^{\Delta r p o E 2}$ varied, but all four genes showed a similar pattern of induction with increases

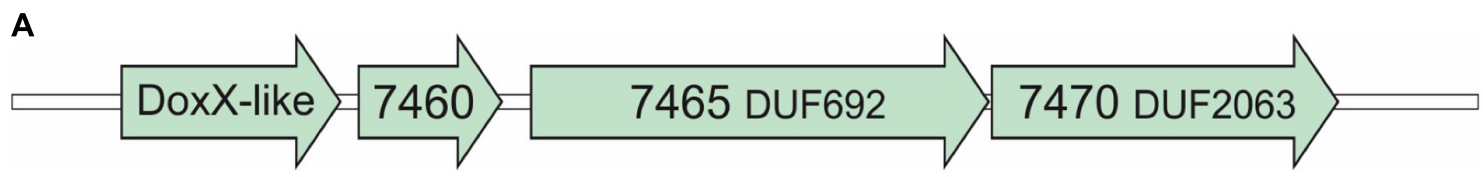

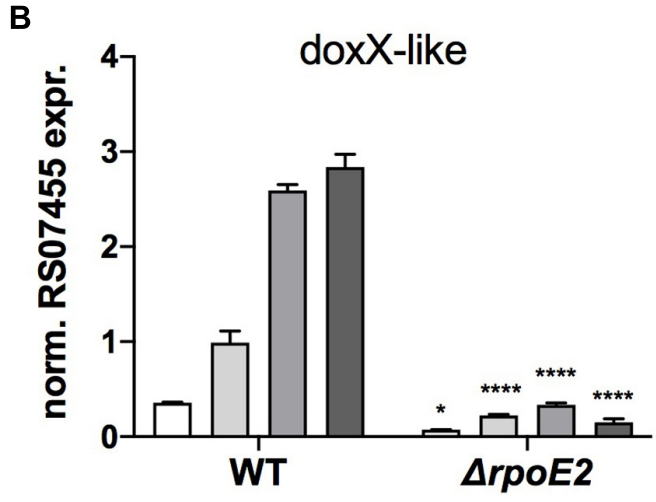

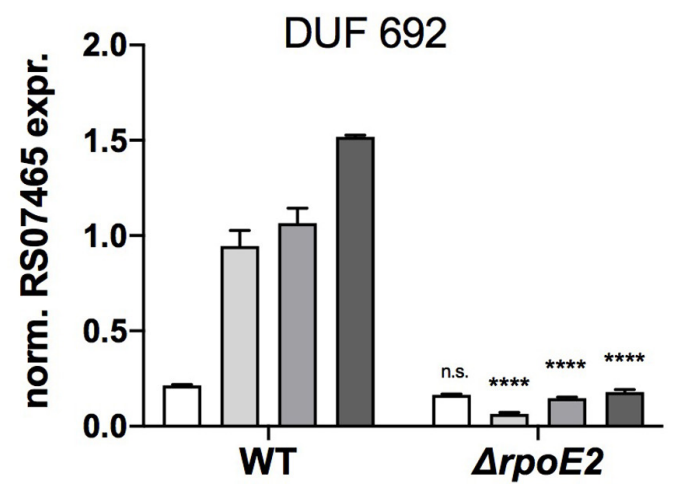

Omin
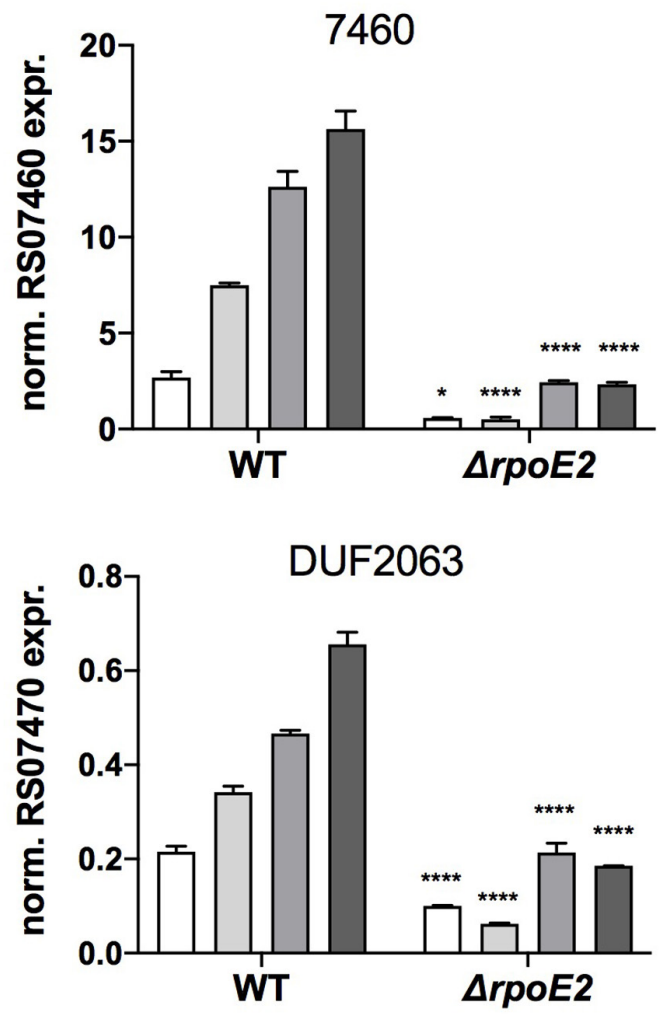

$60 \mathrm{~min} \square 120 \mathrm{~min}$

FIGURE 6 | Expression of putative RpoE2-regulated genes encoding a DoxX-like protein and three putative accessory proteins. (A) gene cluster encoding the Hi2019 doxX gene region. (B) Expression of $H$. influenzae genes encoding a DoxX-like protein (RS07455) and three hypothetical proteins containing conserved domains of unknown function (DUF) - RS07460 (COG3767, periplasmic), RS07465 (COG3220/UPF0276, cytoplasmic), and RS07470 (COG3219, DUF2063, cytoplasmic) - in Hi2019 ${ }^{W T}$ and Hi2019 ${ }^{\Delta r p o E 2}$ following exposure to $200 \mu \mathrm{M} \mathrm{HOCl}$. Gene expression data are reported as relative expression after normalization to expression of the gyrA gene. Statistical testing of expression changes in Hi2019 ${ }^{\Delta r p o E 2}$ relative to Hi2019WT used two-way ANOVA. Statistically significant changes are indicated above the bars representing the gene expression of Hi2019 ${ }^{\Delta r p o E 2}$. ${ }^{\star} p<0.05,{ }^{\star \star} p<0.01,{ }^{\star \star \star} p<0.001$, ${ }^{\star \star \star \star} p<0.0001$; $n$.s., not significant. 
starting $30 \mathrm{~min}$ post-exposure and highest expression levels reached after $120 \mathrm{~min}$ in $\mathrm{Hi} 2019^{\mathrm{WT}}$, a pattern reminiscent of that of the rpoE2 gene. Interestingly, expression of all four genes was strongly RpoE2-dependent, and no significant induction of gene expression was observed in $\mathrm{Hi} 2019^{\triangle \text { rpoE2 }}$ following $\mathrm{HOCl}$ treatment (Figures 6A-D). This demonstrates that functional similarities exist between the HiRpoE2 and Neisseria SigE regulons, and the function of the proteins encoded by the doxX operon should be studied in detail in the future.

\section{DISCUSSION}

The RpoE2 ECF sigma factor is one of only two conserved ECF sigma factors in $H$. influenzae, and here we have shown that RpoE2 is an oxidative stress-responsive alternative sigma factor that regulates functions associated with $\mathrm{HOCl}$ resistance and envelope protein repair.

The activity of RpoE2 is controlled by a small peptide ASF, HrsE, which makes it distinct from the other highly conserved $H$. influenzae ECF sigma factor, RpoE, that is closely related to the well-studied E. coli SigE and, like its E. coli counterpart, is encoded by an operon that also contains genes encoding the membrane-bound RseAB ASF typical of group 1 ECF sigma factors (Craig et al., 2002).

The HiHrsE ASF resembles other ECF group 13 peptide ASFs, all of which share conserved residues involved in binding a zinc ion (ZAS motif) that are also conserved in HiHrsE, suggesting conservation of function between these systems.

HiRpoE2 is most closely related to the SigE ECF sigma factor from Neisseria species. In Neisseria, $\mathrm{H}_{2} \mathrm{O}_{2}$ was reported as an inducer of the SigE response, and mapping of the SigE regulon in $N$. meningitidis found that it consists of only 10 genes, including those encoding NmsigE and its cognate ASF (Gunesekere et al., 2006; Hopman et al., 2010; Huis in 'T Veld et al., 2011). In contrast, here, we have shown that HiRpoE2 gene expression is induced in response to exposure to $\mathrm{HOCl}, \mathrm{H}_{2} \mathrm{O}_{2}$, and paraquat, indicating a much wider role in $H$. influenzae oxidative stress defense and likely protection of $H$. influenzae from thiol stress.

The Neisseria SigE protein was found to be non-essential for host cell interactions in a tissue cell model of infection (Du et al., 2005), and we observed a similar phenotype for our $\mathrm{Hi2019^{ \Delta rpoE2 }}$ strain, as well as an absence of a strong ROS-sensitivity phenotype. However, in a mouse model of infection, Hi2019 ${ }^{\triangle r p o E 2}$ showed reduced fitness evidenced by faster clearance from both lung tissue and the airways, indicating a specific role for this sigma factor in vivo.

These observations may be linked to changes in the expression levels of the $\operatorname{Hims} A B$ gene, which is required for resistance of H. influenzae to $\mathrm{HOCl}$ (Nasreen et al., 2020). In addition, MsrAB was shown to have immunomodulatory effects (Nasreen et al., 2020), and the in vivo phenotype of Hi2019 ${ }^{\Delta \text { rpoE2 }}$ may be related to lower levels of $m s r A B$ expression that affect this function.

Our preliminary exploration of $H$. influenzae genes regulated by RpoE2 indicates that, in addition to $m s r A B$, RpoE2 controls the expression of a conserved gene encoding a DMT-type transporter that is found in the $m s r A B$ gene region and another periplasmic MetSO reductase, MtsZ, as well as genes encoding proteins homologous to members of the Neisseria SigE regulon. Most of these proteins are functionally uncharacterized, but regulation of a gene encoding a DoxX-like protein by RpoE2 is significant, as a DoxX-like protein from Mycobacterium tuberculosis has been shown to form a membrane-bound thiol oxidoreductase complex with an Fe-containing superoxide dismutase and a sulfur transferase, SseA (Nambi et al., 2015).

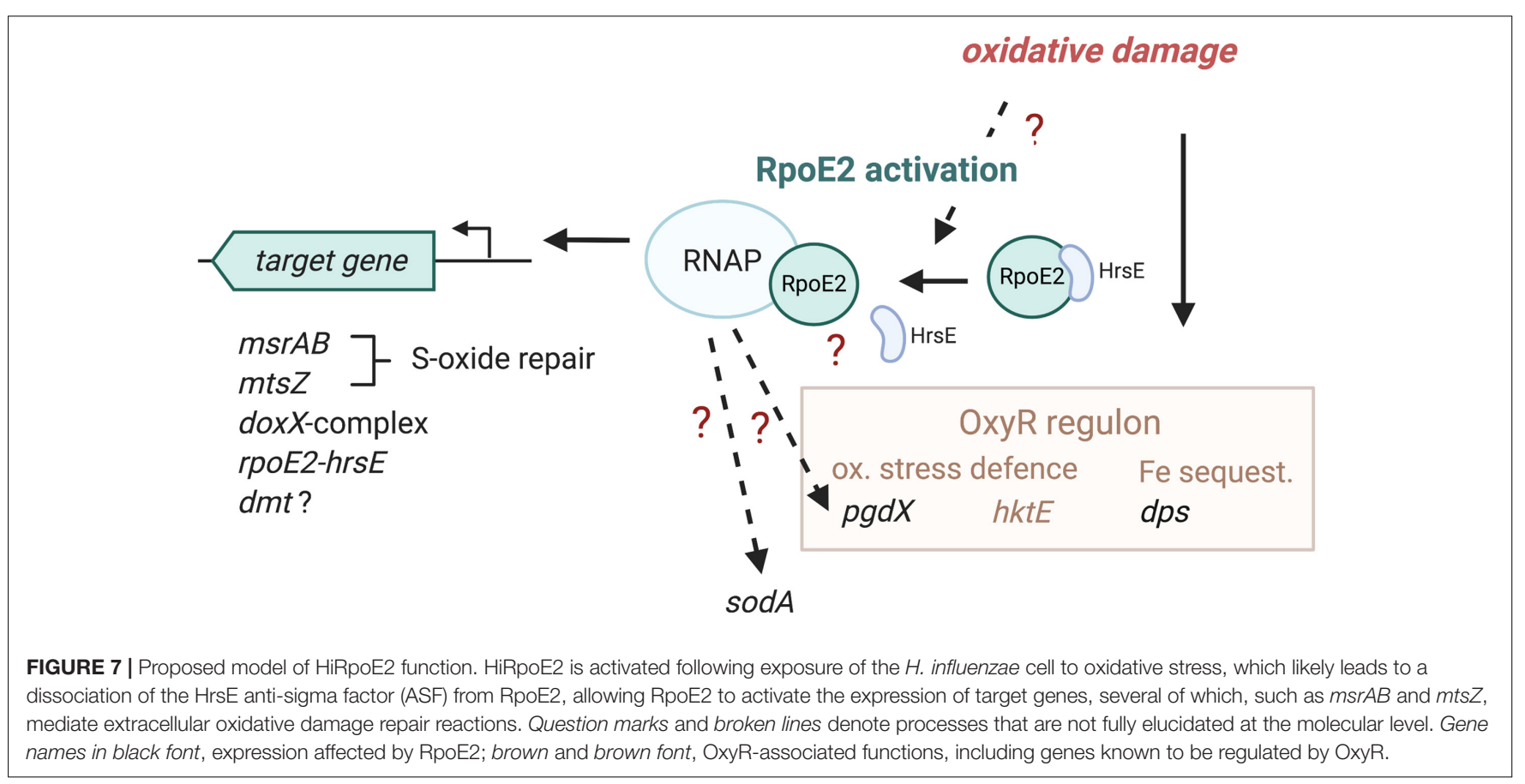


In $M$. tuberculosis, this protein complex maintains mycothiol homeostasis and is required for bacterial survival in mice and activated macrophages (Nambi et al., 2015). The $H$. influenzae DoxX-like membrane protein is encoded in a gene region that also contains genes encoding a periplasmic protein and two potentially cytoplasmic proteins, all of which belong to 'domain of unknown function' groups, and it is a distant relative of the DoxX protein characterized in $M$. tuberculosis.

Our data show that HiRpoE2 is a new element in the $H$. influenzae defense against oxidative stress, where OxyR and also ArcA have previously been identified as major regulators (Harrison et al., 2007; Wong et al., 2007; Whitby et al., 2012). $H$. influenzae OxyR controls the expression of key oxidative stress response enzymes such as catalase and peroxiredoxin, and both regulators contribute to iron sequestration via the expression of, e.g., the ferritin-like Dps protein (OxyR) and a Dps-like protein (ArcA) (Harrison et al., 2007; Wong et al., 2007; Whitby et al., 2012). Notably, both OxyR and ArcA appear to be primarily involved in controlling the expression of enzymes that protect the $H$. influenzae cytoplasm from oxidative stress, while RpoE2 directly regulates the expression of at least two periplasmic enzymes, MtsZ and MsrAB, both of which are involved in the repair of oxidative damage, and an uncharacterized DoxX-containing protein complex that also contains a periplasmic component. An interesting observation is that a certain overlap appears to exist between the OxyR regulon and the HiRpoE2 regulon, where $d p s$ and $p g d X$ expression was altered in Hi2019 ${ }^{\triangle r p o E 2}$ (Figure 7). Our data also indicate that there are additional levels of complexity in RpoE2-based gene regulation as the induction patterns of RpoE2-dependent genes varied, and bioinformatic analyses also identified potential OxyR binding sites upstream of rpoE2, $m s r A B$, and $d m t$.

In summary, we propose that the strictly conserved HiRpoE2 sigma factor is required for maintaining the integrity of $H$. influenzae outer membrane, periplasmic and possible membrane proteins and controls key elements of the $H$. influenzae cell envelope oxidative stress defense.

\section{REFERENCES}

Ausubel, F. M. (2002). Short Protocols in Molecular Biology: A Compendium of Methods from "Current Protocols in Molecular Biology". New York, NY: Wiley.

Ausubel, F. M., Brent, R., Kingston, R. E., Moore, D. D., Seidman, J. G., Smith, J. A., et al. (2005). "Current protocols in molecular biology," in Current Protocols in Molecular Biology, ed. K. Janssen (Hoboken, NJ: John Wiley \& Sons Inc).

Campagnari, A. A., Gupta, M. R., Dudas, K. C., Murphy, T. F., and Apicella, M. A. (1987). Antigenic diversity of lipopolysaccharides on nontypable H. influenzae. Infect. Immun. 55, 882-887. doi: 10.1128/iai.55.4.882-887. 1987

Coleman, H. N., Daines, D. A., Jarisch, J., and Smith, A. L. (2003). Chemically defined media for growth of $H$. influenzae strains. J. Clin. Microbiol. 41, 4408-4410. doi: $10.1128 / \mathrm{jcm} .41 .9 .4408-4410.2003$

Coligan, J. E. (2003). Short Protocols in Protein Science: A Compendium of Methods from Current Protocols in Protein Science. Hoboken, N.J: Wiley.

Craig, J. E., Nobbs, A., and High, N. J. (2002). The extracytoplasmic sigma factor, sigE, is required for intracellular survival of nontypeable $H$. influenzae in J774 macrophages. Infect. Immun. 70, 708-715. doi: 10.1128/iai.70.2.708-715.2002

\section{DATA AVAILABILITY STATEMENT}

The original contributions presented in the study are included in the article/Supplementary Material, further inquiries can be directed to the corresponding author.

\section{ETHICS STATEMENT}

The animal study protocols were approved by Animal Care and Ethics Committees of QIMR Berghofer and the University of Queensland (QIMR/050/19).

\section{AUTHOR CONTRIBUTIONS}

All authors contributed to the writing of the manuscript. MN and AF carried out the bulk of the experimental work. JH and A-TE carried out the mouse infection work. QZ carried out parts of the bioinformatic analyses. UK supervised the experimental work and provided the conceptual framework for the project. AM provided the input into the conceptual framework of the work and contributed to student supervision.

\section{FUNDING}

This work was supported by the National Health and Medical Research Council grant GNT1158451 to UK and AM. MN was a recipient of Schlumberger Foundation Faculty for the Future Scholarship. JH was a recipient of an Australian Postgraduate Training Award.

\section{SUPPLEMENTARY MATERIAL}

The Supplementary Material for this article can be found online at: https://www.frontiersin.org/articles/10.3389/fmicb. 2021.637213/full\#supplementary-material

Dhouib, R., Othman, D. S. M. P., Lin, V., Lai, X. J., Wijesinghe, H. G. S., Essilfie, A.-T., et al. (2016). A novel, Molybdenum-containing methionine sulfoxide reductase supports survival of $H$. influenzae in an in vivo model of infection. Front. Microbiol. 7:1743. doi: 10.3389/fmicb.2016.01743

Du, Y., Lenz, J., and Arvidson, C. G. (2005). Global gene expression and the role of sigma factors in Neisseria gonorrhoeae in interactions with epithelial cells. Infect. Immun. 73, 4834-4845. doi: 10.1128/iai.73.8.4834-4845.2005

Essilfie, A.-T., Horvat, J. C., Kim, R. Y., Mayall, J. R., Pinkerton, J. W., Beckett, E. L., et al. (2015). Macrolide therapy suppresses key features of experimental steroid-sensitive and steroid-insensitive asthma. Thorax 70, 458-467. doi: 10. 1136/thoraxjnl-2014-206067

Essilfie, A. T., Simpson, J. L., Dunkley, M. L., Morgan, L. C., Oliver, B. G., Gibson, P. G., et al. (2012). Combined $H$. influenzae respiratory infection and allergic airways disease drives chronic infection and features of neutrophilic asthma. Thorax 67, 588-599. doi: 10.1136/thoraxjnl-2011-200160

Essilfie, A.-T., Simpson, J. L., Horvat, J. C., Preston, J. A., Dunkley, M. L., Foster, P. S., et al. (2011). H. influenzae infection drives IL-17-mediated neutrophilic allergic airways disease. PLoS Pathog. 7:e1002244. doi: 10.1371/journal.ppat. 1002244 
Finney, L. J., Ritchie, A., Pollard, E., Johnston, S. L., and Mallia, P. (2014). Lower airway colonization and inflammatory response in COPD: a focus on H. influenzae. Int. J. Chron. Obstruct. Pulmon Dis. 9, 1119-1132. doi: 10.2147/ copd.s54477

Gangaiah, D., Zhang, X., Baker, B., Fortney, K. R., Liu, Y., Munson, R. S., et al. (2014). Haemophilus ducreyi RpoE and CpxRA appear to play distinct yet complementary roles in regulation of envelope-related functions. J. Bacteriol. 196, 4012-4025. doi: 10.1128/jb.02034- 14

Gunesekere, I. C., Kahler, C. M., Ryan, C. S., Snyder, L. A. S., Saunders, N. J., Rood, J. I, et al. (2006). Ecf, an alternative sigma factor from Neisseria gonorrhoeae, controls expression of msrAB, which encodes methionine sulfoxide reductase. J. Bacteriol. 188, 3463-3469. doi: 10.1128/jb.188.10.3463-3469. 2006

Hanahan, D., Jessee, J., and Bloom, F. R. (1991). Plasmid transformation of Escherichia coli and other bacteria. Methods Enzymol. 204, 63-113. doi: 10. 1016/0076-6879(91)04006-a

Harrison, A., Bakaletz, L. O., and Munson, R. S. (2012). H. influenzae and oxidative stress. Front. Cell. Infect. Microbiol. 2:40. doi: 10.3389/fcimb.2012. 00040

Harrison, A., Baker, B. D., and Munson, R. S. (2015). Overlapping and complementary oxidative stress defense mechanisms in nontypeable $H$. influenzae. J. Bacteriol. 197, 277-285. doi: 10.1128/jb. 01973-14

Harrison, A., Ray, W. C., Baker, B. D., Armbruster, D. W., Bakaletz, L. O., and Munson, R. S. (2007). The OxyR regulon in nontypeable H. influenzae. J. Bacteriol. 189, 1004-1012. doi: 10.1128/jb.01040-06

Helmann, J. D. (2002). "The extracytoplasmic function (ECF) sigma factors," in Advances in Microbial Physiology, Vol. 46, ed. R. K. Poole (London: Academic Press), 47-110. doi: 10.1016/s0065-2911(02)46002-x

Hopman, C. T., Speijer, D., Van Der Ende, A., and Pannekoek, Y. (2010). Identification of a novel anti-sigmaE factor in Neisseria meningitidis. BMC Microbiol. 10:164. doi: 10.1186/1471-2180-10-164

Huis in 'T Veld, R. A. G., Willemsen, A. M., Van Kampen, A. H. C., Bradley, E. J., Baas, F., Pannekoek, Y., et al. (2011). Deep sequencing whole transcriptome exploration of the $\sigma \mathrm{E}$ regulon in Neisseria meningitidis. PLoS One 6:e29002. doi: 10.1371/journal.pone.0029002

Ilbert, M., Graf, P. C., and Jakob, U. (2006). Zinc center as redox switch-new function for an old motif. Antioxid. Redox Signal. 8, 835-846. doi: 10.1089/ ars.2006.8.835

Johnston, J. W. (2010). Laboratory growth and maintenance of $H$. influenzae. Curr. Protoc. Microbiol. Chapter 6, Unit6D.1.

Kallifidas, D., Thomas, D., Doughty, P., and Paget, M. S. B. (2010). The $\sigma$ R regulon of Streptomyces coelicolor A3(2) reveals a key role in protein quality control during disulphide stress. Microbiology 156, 1661-1672. doi: 10.1099/mic.0. 037804-0

Kang, J. G., Paget, M. S., Seok, Y. J., Hahn, M. Y., Bae, J. B., Hahn, J. S., et al. (1999). RsrA, an anti-sigma factor regulated by redox change. EMBO J. 18, 4292-4298. doi: $10.1093 /$ emboj/18.15.4292

King, P. (2012). H. influenzae and the lung (Haemophilus and the lung). Clin. Transl. Med. 1, 10.

King, P. T., and Sharma, R. (2015). The lung immune response to nontypeable H. influenzae (Lung immunity to NTHi). J. Immunol. Res. 2015, 706376706376.

Kroll, J. S., Langford, P. R., Saah, J. R., and Loynds, B. M. (1993). Molecular and genetic characterization of superoxide dismutase in $H$. influenzae type b. Mol. Microbiol. 10, 839-848. doi: 10.1111/j.1365-2958.1993.tb00954.x

Kumar, S., Stecher, G., and Tamura, K. (2016). MEGA7: molecular evolutionary genetics analysis version 7.0 for bigger datasets. Mol. Biol. Evol. 33, 1870-1874. doi: 10.1093/molbev/msw054

Laemmli, U. K. (1970). Cleavage of structural protein during the assembly of the head of bacteriophage T4. Nature 227, 680-685. doi: 10.1038/227680a0

Lichtenegger, S., Bina, I., Durakovic, S., Glaser, P., Tutz, S., Schild, S., et al. (2017). Serum resistance and phase variation of a nasopharyngeal non-typeable H. influenzae isolate. Int. J. Med. Microbiol. 307, 139-146. doi: 10.1016/j.ijmm. 2017.01.005

Macneil, J. R., Cohn, A. C., Farley, M., Mair, R., Baumbach, J., Bennett, N., et al. (2011). Current epidemiology and trends in invasive $H$. influenzae diseaseUnited States, 1989-2008. Clin. Infect. Dis. 53, 1230-1236. doi: 10.1093/cid/ cir735
Mascher, T. (2013). Signaling diversity and evolution of extracytoplasmic function (ECF) $\sigma$ factors. Curr. Opin. Microbiol. 16, 148-155. doi: 10.1016/j.mib.2013. 02.001

Miller, J. H. (1972). Experiments in Molecular Genetics. Cold Spring Harbor, NY: Cold Spring Harbor Laboratory.

Münch, R., Hiller, K., Grote, A., Scheer, M., Klein, J., Schobert, M., et al. (2005). Virtual Footprint and PRODORIC: an integrative framework for regulon prediction in prokaryotes. Bioinformatics 21, 4187-4189. doi: 10.1093/ bioinformatics/bti635

Nambi, S., Long, J. E., Mishra, B. B., Baker, R., Murphy, K. C., Olive, A. J., et al. (2015). The oxidative stress network of Mycobacterium tuberculosis reveals coordination between radical detoxification systems. Cell Host Microbe 17, 829-837. doi: 10.1016/j.chom.2015.05.008

Nasreen, M., Dhouib, R., Hosmer, J., Wijesinghe, H. G. S., Fletcher, A., Mahawar, M., et al. (2020). Peptide methionine sulfoxide reductase from $H$. influenzae is required for protection against $\mathrm{HOCl}$ and affects the host response to infection. ACS Infect. Dis. 6, 1928-1939. doi: 10.1021/acsinfecdis.0c00242

Newman, J. D., Anthony, J. R., and Donohue, T. J. (2001). The importance of zinc-binding to the function of Rhodobacter sphaeroides ChrR as an anti-sigma factor. J. Mol. Biol. 313, 485-499. doi: 10.1006/jmbi.2001.5069

Othman, D. S. M. P., Schirra, H. J., Mcewan, A. G., and Kappler, U. (2014). Metabolic versatility in $H$. influenzae: a metabolomic and genomic analysis. Front. Microbiol. 5:69. doi: 10.3389/fmicb.2014.00069

Paget, M. S., Bae, J. B., Hahn, M. Y., Li, W., Kleanthous, C., Roe, J. H., et al. (2001). Mutational analysis of RsrA, a zinc-binding anti-sigma factor with a thiol-disulphide redox switch. Mol. Microbiol. 39, 1036-1047. doi: 10.1046/j. 1365-2958.2001.02298.x

Paget, M. S., Kang, J. G., Roe, J. H., and Buttner, M. J. (1998). sigmaR, an RNA polymerase sigma factor that modulates expression of the thioredoxin system in response to oxidative stress in Streptomyces coelicolor A3(2). EMBO J. 17, 5776-5782. doi: 10.1093/emboj/17.19.5776

Park, J.-H., Lee, J.-H., and Roe, J.-H. (2019). SigR, a hub of multilayered regulation of redox and antibiotic stress responses. Mol. Microbiol. 112, 420-431. doi: $10.1111 / \mathrm{mmi} .14341$

Pettigrew, M. M., Laufer, A. S., Gent, J. F., Kong, Y., Fennie, K. P., and Metlay, J. P. (2012). Upper respiratory tract microbial communities, acute otitis media pathogens, and antibiotic use in healthy and sick children. Appl. Environ. Microbiol. 78, 6262-6270. doi: 10.1128/aem.01051-12

Pinto, D., and Mascher, T. (2016). "The ECF classification: a phylogenetic reflection of the regulatory diversity in the extracytoplasmic function $\sigma$ factor protein family," in Stress and Environmental Regulation of Gene Expression and Adaptation in Bacteria, ed. F. J. Debruijn (Hoboken, NJ: John Wiley \& Sons), 64-96. doi: 10.1002/9781119004813.ch7

Poje, G., and Redfield, R. J. (2003). "Transformation of H. influenzae," in H. influenzae Protocols, eds M. A. Herbert, D. W. Hood, and E. R. Moxon (Totowa, NJ: Humana Press), 57-70. doi: 10.1385/1-59259-321-6:57

Praszkier, J., Wilson, I. W., and Pittard, A. J. (1992). Mutations affecting translational coupling between the rep genes of an IncB miniplasmid. J. Bacteriol. 174, 2376-2383. doi: 10.1128/jb.174.7.2376-2383.1992

Roach, D. J., Burton, J. N., Lee, C., Stackhouse, B., Butler-Wu, S. M., Cookson, B. T., et al. (2015). A year of infection in the intensive care unit: prospective whole genome sequencing of bacterial clinical isolates reveals cryptic transmissions and novel microbiota. PLoS Genetics 11:e1005413. doi: 10.1371/journal.pgen. 1005413

Ruijter, J., Ramakers, C., Hoogaars, W., Karlen, Y., Bakker, O., Van Den Hoff, M., et al. (2009). Amplification efficiency: linking baseline and bias in the analysis of quantitative PCR data. Nucleic Acids Res. 37, e45. doi: 10.1093/nar/gkp045

Schembri, M. A., and Klemm, P. (2001). Biofilm formation in a hydrodynamic environment by novel fimh variants and ramifications for virulence. Infect. Immun. 69, 1322-1328. doi: 10.1128/iai.69.3.1322-1328.2001

Sievers, F., Wilm, A., Dineen, D., Gibson, T. J., Karplus, K., Li, W., et al. (2011). Fast, scalable generation of high-quality protein multiple sequence alignments using Clustal Omega. Mol. Syst. Biol. 7, 539. doi: 10.1038/msb.2011.75

Slack, M. P. E. (2015). A review of the role of $H$. influenzae in community-acquired pneumonia. Pneumonia 6, 26-43. doi: 10.15172/pneu.2015.6/520

Soeters, H. M., Blain, A., Pondo, T., Doman, B., Farley, M. M., Harrison, L. H., et al. (2018). Current epidemiology and trends in invasive $H$. influenzae disease United States, 2009-2015. Clinical Infectious Diseases 67, 881-889. doi: 10.1093/ cid/ciy187 
Staroń, A., Sofia, H. J., Dietrich, S., Ulrich, L. E., Liesegang, H., and Mascher, T. (2009). The third pillar of bacterial signal transduction: classification of the extracytoplasmic function (ECF) $\sigma$ factor protein family. Mol. Microbiol. 74, 557-581. doi: 10.1111/j.1365-2958.2009.06870.x

Tristram, S., Jacobs, M., and Appelbaum, P. (2007). Antimicrobial resistance in H. influenzae. Clin. Microbiol. Rev. 20, 368-389.

Van Eldere, J., Slack, M. P. E., Ladhani, S., and Cripps, A. W. (2014). Non-typeable H. influenzae, an under-recognised pathogen. Lancet Infect. Dis. 14, 1281-1292. doi: 10.1016/s1473-3099(14)70734-0

Vieira, J., and Messing, J. (1982). The pUC plasmids, an M13mp7-derived system for insertion mutagenesis and sequencing with synthetic universal primers. Gene 19, 259-268. doi: 10.1016/0378-1119(82)90015-4

Wan Sai Cheong, J., Smith, H., Heney, C., Robson, J., Schlebusch, S., Fu, J., et al. (2015). Trends in the epidemiology of invasive $H$. influenzae disease in Queensland, Australia from 2000 to 2013: what is the impact of an increase in invasive non-typable H. influenzae (NTHi)? Epidemiol. Infect. 143, 2993-3000. doi: $10.1017 / \mathrm{s} 0950268815000345$

Whitby, P. W., Morton, D. J., Vanwagoner, T. M., Seale, T. W., Cole, B. K., Mussa, H. J., et al. (2012). H. influenzae OxyR: characterization of its regulation, regulon and role in fitness. PLoS One 7:e50588. doi: 10.1371/journal.pone. 0050588
Wong, S. M. S., Alugupalli, K. R., Ram, S., and Akerley, B. J. (2007). The ArcA regulon and oxidative stress resistance in $H$. influenzae. Mol. Microbiol. 64, 1375-1390. doi: 10.1111/j.1365-2958.2007. 05747.x

World Health Organization. (2017). Global Priority List of AntibioticResistant Bacteria to Guide Research, Discovery, and Development of New Antibiotics. Available online at: https://www.who.int/medicines/publications/ global-priority-list-antibiotic-resistant-bacteria/en/ (accessed February 8, 2019).

Conflict of Interest: The authors declare that the research was conducted in the absence of any commercial or financial relationships that could be construed as a potential conflict of interest.

Copyright (C) 2021 Nasreen, Fletcher, Hosmer, Zhong, Essilfie, McEwan and Kappler. This is an open-access article distributed under the terms of the Creative Commons Attribution License (CC BY). The use, distribution or reproduction in other forums is permitted, provided the original author(s) and the copyright owner(s) are credited and that the original publication in this journal is cited, in accordance with accepted academic practice. No use, distribution or reproduction is permitted which does not comply with these terms. 